\title{
The social dimension of globalization: a review of the literature
}

Working Paper No. 24

Bernhard G. Gunter

and

Rolph van der Hoeven

Policy Integration Department

World Commission on the Social Dimension of Globalization

International Labour Office

Geneva

June 2004 


\section{Copyright (C) International Labour Organization 2004}

Publications of the International Labour Office enjoy copyright under Protocol 2 of the Universal Copyright Convention. Nevertheless, short excerpts from them may be reproduced without authorization, on condition that the source is indicated. For rights of reproduction or translation, application should be made to the Publications Bureau (Rights and Permissions), International Labour Office, CH-1211 Geneva 22, Switzerland. The International Labour Office welcomes such applications.

Libraries, institutions and other users registered in the United Kingdom with the Copyright Licensing Agency, 90 Tottenham Court Road, London W1T 4LP [Fax: (+44) (0)20 7631 5500; email: cla@cla.co.uk], in the United States with the Copyright Clearance Center, 222 Rosewood Drive, Danvers, MA 01923 [Fax: (+1) (978) 750 4470; email: info@,copyright.com] or in other countries with associated Reproduction Rights Organizations, may make photocopies in accordance with the licences issued to them for this purpose.

\section{ISBN 92-2-116312-1 (printed version) \\ 92-2-116313-X (web version )}

First published 2004

Cover:

The designations employed in ILO publications, which are in conformity with United Nations practice, and the presentation of material therein do not imply the expression of any opinion whatsoever on the part of the International Labour Office concerning the legal status of any country, area or territory or of its authorities, or concerning the delimitation of its frontiers.

The responsibility for opinions expressed in signed articles, studies and other contributions rests solely with their authors, and publication does not constitute an endorsement by the International Labour Office of the opinions expressed in them.

Reference to names of firms and commercial products and processes does not imply their endorsement by the International Labour Office, and any failure to mention a particular firm, commercial product or process is not a sign of disapproval.

ILO publications can be obtained through major booksellers or ILO local offices in many countries, or direct from ILO Publications, International Labour Office, $\mathrm{CH}-1211$ Geneva 22, Switzerland. Catalogues or lists of new publications are available free of charge from the above address, or by email: pubvente@ilo.org

Visit our website: www.ilo.org/publns 


\section{The social dimension of globalization: a review of the literature}

\section{Contents}

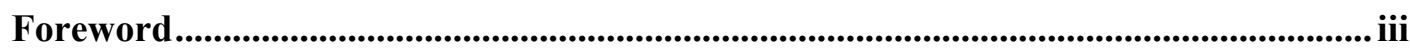

Preface. $\mathbf{v}$

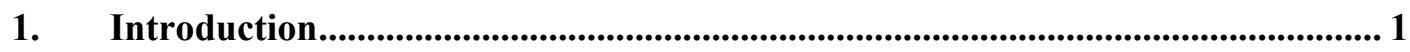

2. Key economic characteristics of the recent globalization process ........................2

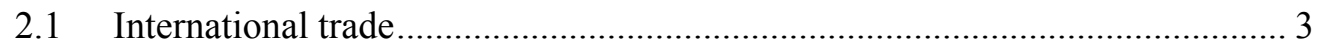

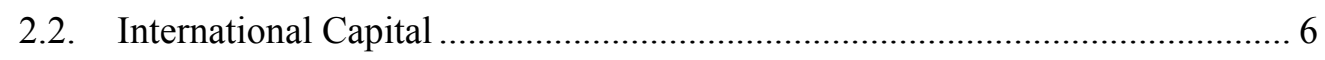

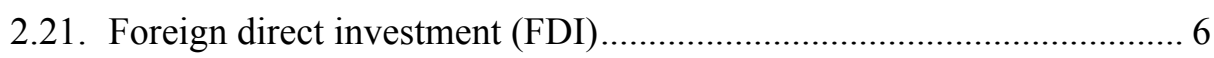

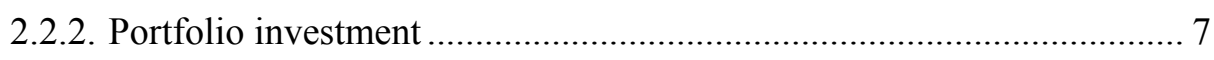

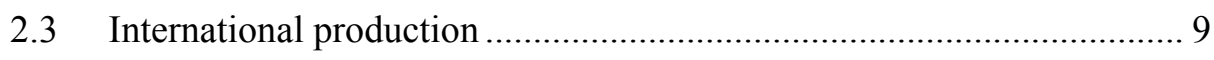

3. The recent globalization process and its social dimension ...................................... 10

3.1. Global Pressure on Wages and Employment …......................................... 10

3.2 Controversies of the impact of globalization on poverty............................. 12

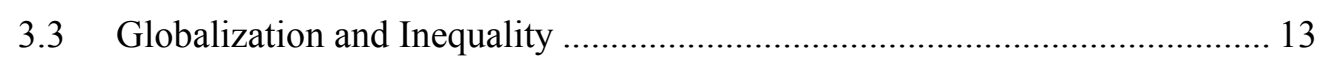

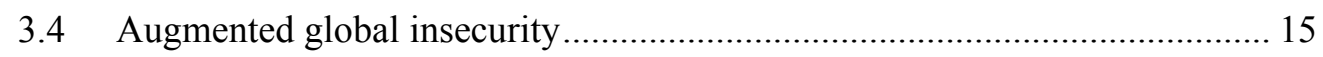

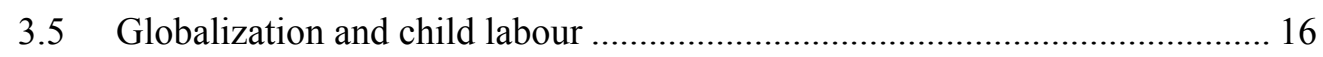

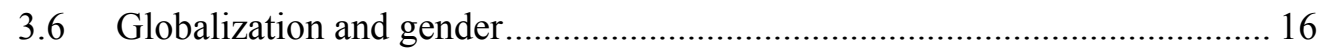

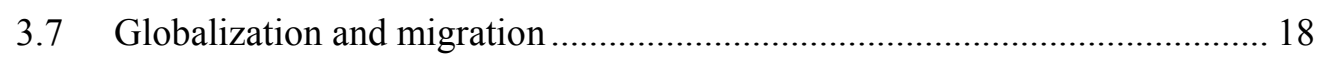

4. National and international policy responses......................................................... 19

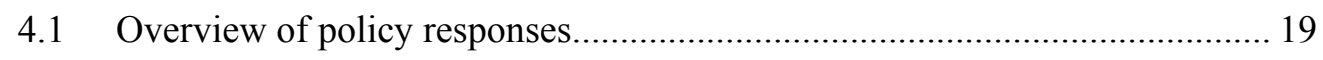

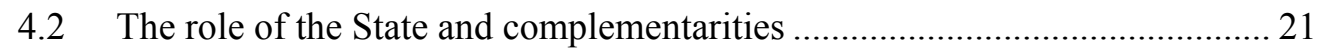

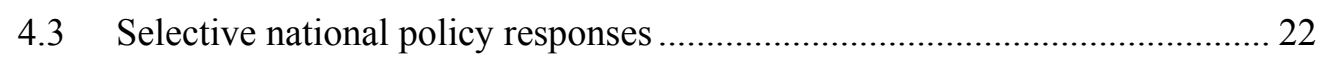

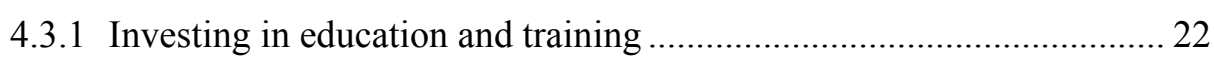

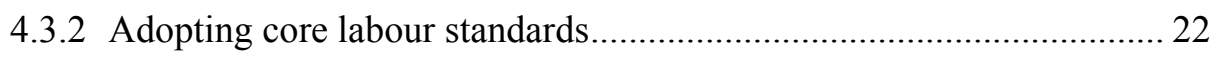

4.3.3 Providing and improving social protection ....................................... 23 


\title{
The social dimension of globalization: a review of the literature
}

\author{
Contents (continued)
}

4.3.4 Addressing increasing national income inequality 23

4.3.5 Providing space for discussing globalization 23

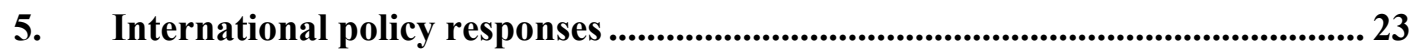

5.1 A development round of trade negotiations ............................................... 24

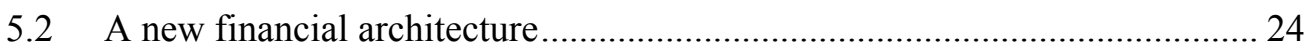

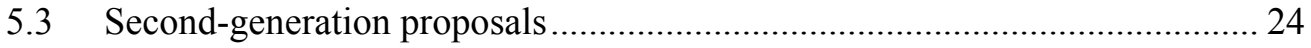

5.4 Policy actions that require international agreements .................................... 25

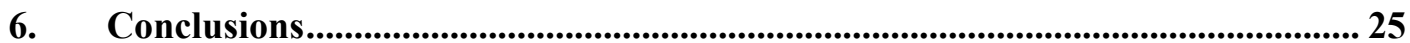

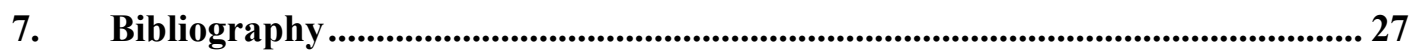




\title{
Foreword
}

In February 2002, the ILO established an independent World Commission on the Social Dimension of Globalization, co-chaired by President Tarja Halonen of Finland and President Benjamin Mkapa of Tanzania and comprising 26 eminent commissioners from a wide range of walks of life and different parts of the world, each serving in their individual capacity. Its broad goals were: to identify policies for globalization that reduce poverty, foster growth and development in open economies, and widen opportunities for decent work; to explore ways to make globalization inclusive, so that the process can be seen to be fair for all, both between and within countries; to promote a more focused international dialogue on the social dimension of globalization; to build consensus among key actors and stakeholders on appropriate policy responses; and to assist the international community forge greater policy coherence in order to advance both economic and social goals in the global economy.

The report of the World Commission, A fair globalization: Creating opportunities for all, was released on 24 February 2004. It is available on the Commission's website www.ilo.org/public/english/wcsdg/index.htm.

A secretariat was established by the ILO to support the Commission. Among other tasks, it compiled information and commissioned papers on different aspects of the social dimension of globalization. The aim was to provide the Commission with documentation and data on a wide range of options and opinions concerning subjects within its mandate, without committing the Commission or individual Commissioners to any particular position on the issues or policies concerned.

Material from this background work is being made available as working papers, as national and regional reports on meetings and dialogues, and in other forms. Responsibility for the content of these papers and publications rests fully with their authors and their publication does not constitute an endorsement by the World Commission or the ILO of the opinions expressed in them.

\author{
Gerry Rodgers \\ Director \\ Policy Integration Department
}




\title{
Preface
}

The Technical Secretariat to support the World Commission on the Social Dimension of Globalization first prepared a synthesis of ILO activities on the Social Dimension of Globalization (published as Working Paper No. 1 in this series). Documentation on the work and outcomes of other major commissions, an ideas bank, a database and knowledge networks of experts and social actors were subsequently developed. These networks have dealt with several topics, including: inclusion at the national level for the benefits of globalization to reach more people; local markets and policies; cross-border networks of production to promote decent work, growth and development; international migration as part of the Global Policy Agenda; international governance (including trade and finance); the relationship between culture and globalization; and values and goals in globalization. Gender and employment aspects were addressed throughout this work. The Reports on the Secretariat's Knowledge Network Meetings are available on the Commission's web site or in a special publication from the ILO (ISBN 92-2-115711-1).

During the course of these activities, a number of substantive background papers were prepared, which are now made available for wider circulation in the Policy Integration Department's Working Paper series (Nos. 16 to 38), as well as on the Commission's website.

The term globalization is used in many different contexts. In this literature review globalization is taken to mean the gradual integration of economies and societies driven by new technologies, new economic relationships and the national and international policies of a wide range of actors, including governments, international organizations, business, labour and civil society. From a conceptual point of view the authors argue that it is useful to split the globalization process into two parts. The first concerns factors such as trade, investment, technology, cross-border production systems, information flows, and communication. Though all these factors may have brought some economies and some societies closer together, they may have also marginalized many countries and individuals. The second aspect of the globalization process concerns the increased homogenization of policies and institutions across the world, e.g. trade and capital market liberalization; the dismantling of the welfare state; international agreements on intellectual property rights; and the standardization of policies and behaviours that have promoted globalization. While the first aspect is irreversible, the second is not inevitable but the result of policy choices.

The social dimension of globalization relates to the impact of globalization on the life and work of people, their families, and their societies. Beyond the world of work, the social dimension includes security, culture and identity, inclusion or exclusion from society, and the cohesiveness of families and communities. This literature review considers the impact of economic globalization on wages and taxes, poverty, inequality, insecurity, child labour, gender, and migration. The intention of this survey is not to present the broad spectrum of contrasting views that exists in the literature, but to summarize some recent significant articles and publications on the various social dimensions of the economic globalization process, and to suggest some key policy responses to make globalization a fairer and more sustainable process for all.

\author{
Rolph van der Hoeven \\ Manager, Technical Secretariat \\ World Commission on the Social Dimension of Globalization
}

June 2004 


\section{The social dimension of globalization: a review of the literature}

\section{Introduction}

Globalization is a term that is used in many ways, but the principal underlying idea is the progressive integration of economies and societies. It is driven by new technologies, new economic relationships and the national and international policies of a wide range of actors, including governments, international organizations, business, labour and civil society. While suggestions have been made to distinguish between specific parts of globalization (like increased international trade) and parallel developments (like technological advances), others have pointed out that a separation of interconnected processes is not feasible.

However, it is useful to split the current globalization process into two aspects. The first refers to elements like trade, investment, technology, cross-border production systems, and flows of information and communication, which on the one hand brings economies and societies closer together, yet, on the other hand also marginalizes a large portion of countries and people. There are justified concerns that due to further globalization, especially in form of a knowledge-driven world, more and more people may become marginalized. The second aspect refers to homogenized policies and institutions, such as: (a) trade and capital market liberalization; (b) international standards for labour and the environment; (c) agreements on intellectual property rights; and (d) other standardization of policies and behaviours. In terms of the latter aspect, the existing pattern of globalization is not an inevitable trend - it is at least in part the product of policy choices. While technological change is irreversible, policies can be changed. Depending on what policies are pursued, the outcome can be influenced with many variations in the social dimension of the globalization process.

The social dimension of globalization refers to the impact of globalization on the life and work of people, on their families, and their societies. Concerns and issues are often raised about the impact of globalization on employment, working conditions, income and social protection. Beyond the world of work, the social dimension encompasses security, culture and identity, inclusion or exclusion, and the cohesiveness of families and communities. In this paper, we look at the impacts of globalization on wages and taxes, poverty, inequality, insecurity, child labour, gender, and migration. 
In early 2002, the International Labour Organization (ILO) launched the World Commission on the Social Dimension of Globalization (WCSDG). The goal of the Commission is to examine ways in which national and international institutions and organizations can contribute to a more inclusive globalization process that is acceptable and fair to all. ${ }^{1}$ The Commission is an unprecedented effort to promote national and international dialogues on ideas to make globalization more inclusive, at a time when the debate is dominated more by polemics and preconceptions than by facts. Its ultimate goal is to use the process of globalization as a resource to reduce poverty and unemployment, to foster growth and sustainable development.

The intention of this literature survey is not to present the large spectrum of contrasting views as it exists in the literature, but to provide a synthesis of recent and salient articles and publications with respect to the various dimensions of the ongoing globalization process and what some of the key policy responses are to make globalization a more sustainable and fair process for all. This literature review is based on a larger collection of over 1,000 articles and books, of which more than two-thirds were published since January 2000 listed at the World Commission web site: www.ilo.org/public/english/wcsdg

The reminder of this paper is structured as follows. First, we review briefly the key economic characteristics of the globalization process, as it is ongoing since 1985 (section 2); this will provide us with the economic context of globalization. We then look in section 3 at various social impacts of this recent globalization process as it can be summarized based on the recent and salient literature. As we will see, while some aspects remain highly controversial, there are some aspects where a consensus seems to emerge. Based on this emerging consensus on some of the social impacts of globalization, section 4 reviews a variety of national policy responses and section 5 a variety of international policy responses. Section 6 contains some conclusions. section 7 contains the bibliography.

\section{Key economic characteristics of the recent globalization process}

The main purpose of this section is to present some stylized facts of the economic characteristics of the recent globalization process, as it is useful to better understand the social impacts of globalization. We first review the increase in international trade, whereby we look shortly at some of the key policy factors for the increase in international trade: global reductions in both tariffs and non-tariff barriers. We then review the increase in international capital transactions as they were encouraged by the increased removal of: (a) restrictions on foreign investment; (b) capital controls; and (c) restrictions on foreign ownership of assets. Third, we look shortly at the increase in international production, which is dominated by the multinational corporations' fragmentation of the production process. To the degree that appropriate data is available, we differentiate between low-income, middle-income, and high-income countries, which will provide some background on the asymmetric distribution of the recent economic globalization.

\footnotetext{
${ }^{1}$ The Commission is chaired by two Heads of State, Finnish President Tarja Halonen and President Benjamin Mkapa of Tanzania. Its members are drawn from all regions of the world. Its report "A fair globalization: Creating Opportunities for all" was released on February $24^{\text {th }} 2004$.
} 
As table 1 shows, world trade (measured by nominal world exports of goods and services) more than tripled from US\$2.3 trillion in 1985 to over US\$7.8 trillion in 2002. During the same period, world nominal GDP (gross domestic product) increased by less than three times (from US\$12.8 trillion in 1985 to US\$32.1 trillion in 2002). A positive difference between the growth rate of world trade minus the growth rate of world GDP is defined as the speed of trade integration. The speed of integration varies across regions, with Latin America and East Asia slowing down and high-income OECD countries accelerating. However, the ratio of exports to GDP fell in about one-third of the 174 countries with sufficient data) between 1985 and 2002, reflecting trade disintegration. For 12 countries all of which are developing countries - the ratio fell more than 20 percentage points between 1985 and 2002.

Table 1. Evolution of income, exports and capital flows, 1985-2002

Evolution of income, exports, and capital flows, 1985-2002

\begin{tabular}{|c|c|c|c|c|c|}
\hline & \multicolumn{2}{|c|}{ Billion of US\$ } & \multirow{2}{*}{$\begin{array}{c}\text { Increase of } 2002 \\
\text { compared to } \\
1985\end{array}$} & \multicolumn{2}{|c|}{$\begin{array}{c}\text { Percentage share } \\
\text { of world level }\end{array}$} \\
\hline & 1985 & 2002 & & 1985 & 2002 \\
\hline \multicolumn{6}{|l|}{ Gross domestic product (GDP) } \\
\hline China and India & 558.5 & $1,922.4$ & 3.4 fold increase & 4.4 & 6.0 \\
\hline Low-income countries, excl. India & 579.3 & 634.7 & 1.1 fold increase & 4.5 & 2.0 \\
\hline Middle-income countries, excl. China & $2,234.1$ & $3,702.9$ & 1.7 fold increase & 17.5 & 11.5 \\
\hline High-income countries & $9,393.4$ & $25,867.0$ & 2.8 fold increase & 73.6 & 80.5 \\
\hline World & $12,765.2$ & $32,127.0$ & 2.5 fold increase & 100.0 & 100.0 \\
\hline \multicolumn{6}{|l|}{ Exports of goods and services } \\
\hline China and India & 79.1 & 685.1 & 8.7 fold increase & 3.4 & 8.7 \\
\hline Low-income countries, excl. India & 82.5 & 215.2 & 2.6 fold increase & 3.6 & 2.7 \\
\hline Middle-income countries, excl. China & 433.9 & $1,227.2$ & 2.8 fold increase & 18.7 & 15.6 \\
\hline High-income countries & $1,718.7$ & $5,732.6$ & 3.3 fold increase & 74.3 & 72.9 \\
\hline World & $2,314.1$ & $7,860.2$ & 3.4 fold increase & 100.0 & 100.0 \\
\hline \multicolumn{6}{|l|}{ Inflows of foreign direct investment } \\
\hline China and India & 1.7 & 62.0 & 37.4 fold increase & 2.9 & 9.8 \\
\hline Low-income countries, excl. India & 1.9 & 7.1 & 3.7 fold increase & 3.3 & 1.1 \\
\hline Middle-income countries, excl. China & 9.7 & 79.1 & 8.1 fold increase & 16.8 & 12.5 \\
\hline High-income countries & 44.7 & 484.3 & 10.8 fold increase & 77.1 & 76.6 \\
\hline World & 58.0 & 632.6 & 10.9 fold increase & 100.0 & 100.0 \\
\hline \multicolumn{6}{|l|}{ Inflows of total portfolio investment } \\
\hline China and India & 2.3 & 49.8 & 22.0 fold increase & 1.7 & 6.9 \\
\hline Low-income countries, excl. India & 0.05 & 0.07 & 1.3 fold increase & 0.038 & 0.009 \\
\hline Middle-income countries, excl. China & 9.1 & 30.0 & 3.3 fold increase & 6.7 & 4.2 \\
\hline High-income countries & 123.8 & 639.9 & 5.2 fold increase & 91.6 & 88.9 \\
\hline World & 135.2 & 719.8 & 5.3 fold increase & 100.0 & 100.0 \\
\hline
\end{tabular}

Sources : Country classifications based on World Bank, Global Development Finance 2003. Data on gross domestic product and exports of goods and services are taken from the IMF's World Economic Outlook. Data on capital flows are taken from the IMF's International Financial Statistics. Data for 2002 may be preliminary for some countries. 
Much of the increase in international trade is due to global trade liberalizations. Until the early 1990s, developing countries had generally higher levels of protection than industrialized countries as trade policy had previously been used to foster industrial development. Higher levels of protection have also been intended to avoid balance of payments crises. Comparisons of the 1980s found that developing countries tariffs were on average about four times higher than industrialized countries' tariffs. Non-tariff barriers (NTBs) of developing countries covered more than twice the share of import categories covered by industrialized countries' NTBs. However, during the last decade, many developing countries have liberalized their tariff regimes by simplifying tariff structures, reducing rates, and sometimes also eliminating NTBs. Import growth of developing countries jumped in the early nineties to more than five times the growth rate of the early eighties. Latin-America is the continent where tariff liberalization went furthest.

As we can see from the third column of table 1, exports of goods and services have increased by multiples from 1985 to 2002 for all four country groups: (i) China and India; (ii) the low-income countries excluding India; (iii) the middle-income countries excluding China; and (iv) the high-income countries. The increase is the largest for China and India combined, followed by the high-income countries. The increase is the lowest for the group of low-income countries excluding India. Hence, the share of the low-income countries excluding India in world trade (calculated in the last two columns of table 1) has actually decreased over the last 17 years (from 3.6 per cent in 1985 to 2.7 per cent in 2002), implying a marginalization in terms of world trade. Note that their share in world GDP has decreased even more drastically (from 4.5 per cent in 1985 to 2.0 per cent in 2002), reflecting an even stronger marginalization in terms of world income. Even the middle-income countries (excluding China) have lost in terms of world market share of income and trade. High-income countries gained in terms of their share in world income, while experiencing a slight reduction in their share of world exports, reflecting the very sharp increase in the trade share of China and India.

When looking at these figures of trade measured in US dollars, we should keep in mind that there have been considerable changes in the terms of trade, with the group of middleand high-income countries experiencing increasing terms of trade at the costs of the low-income countries (see figure 1). Hence, while the marginalization of most low-income countries would be less severe if looking at trade volumes, the decreasing terms of trade implies a formidable challenge for low-income countries. 


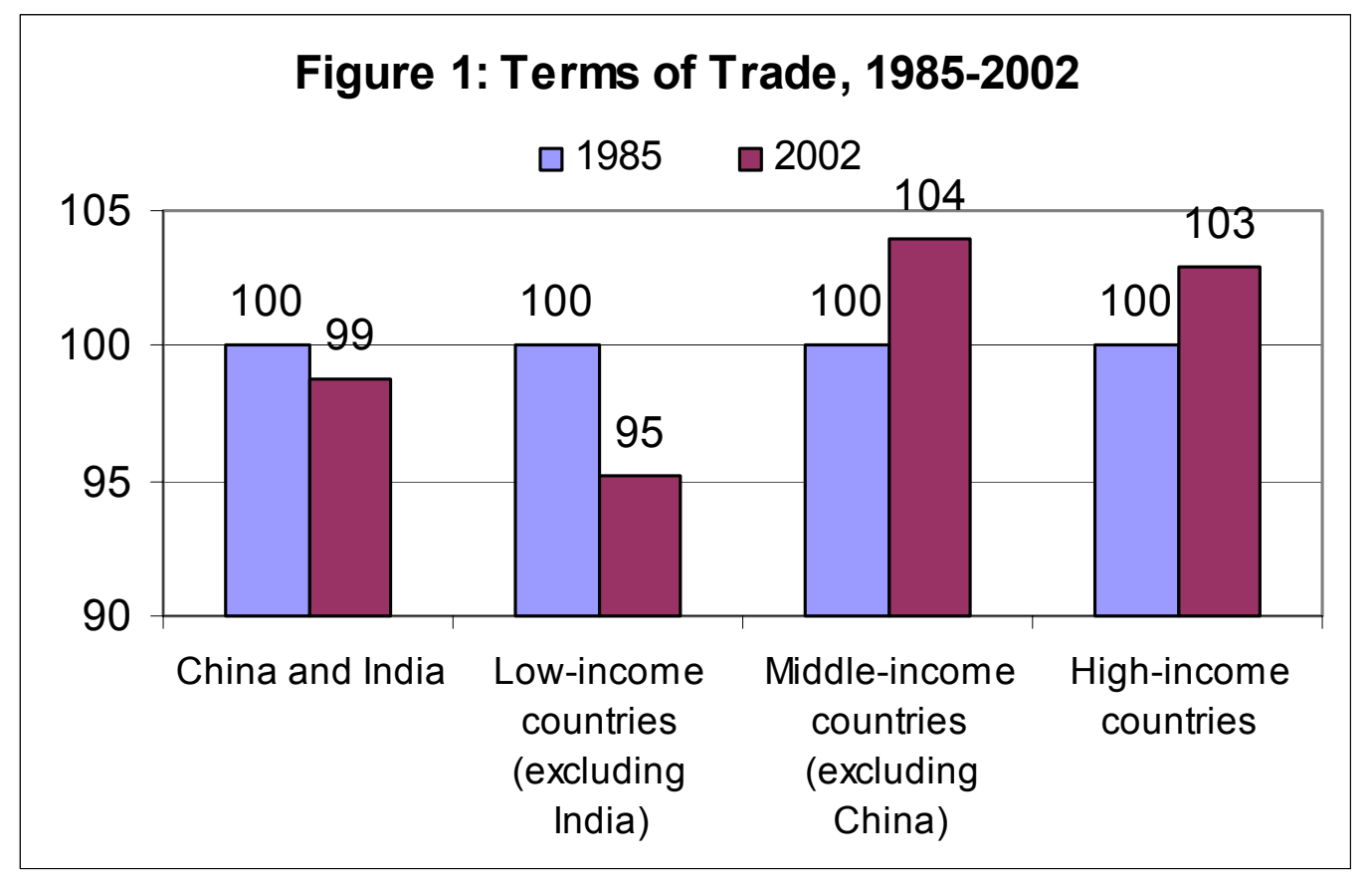

Source: World Bank, World Development Indicators 2003; and IMF, World Economic Outlook, 2003.

Figures 2 and 3 provide the annual changes in gross domestic product (GDP) and exports of goods and services, respectively, for our four country-groups from 1985-2002, which clearly shows the marginalization of the low-income countries (shown as the thin red line on the bottom of each figure).

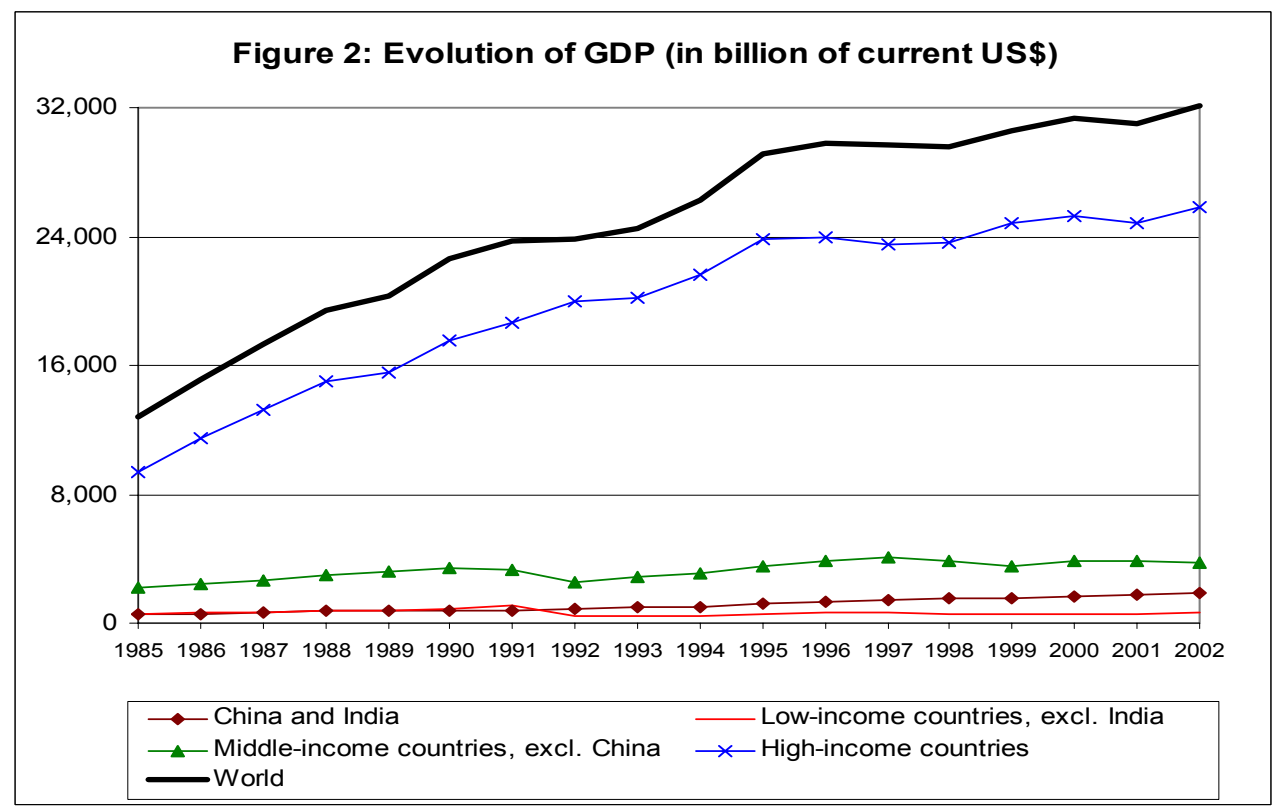




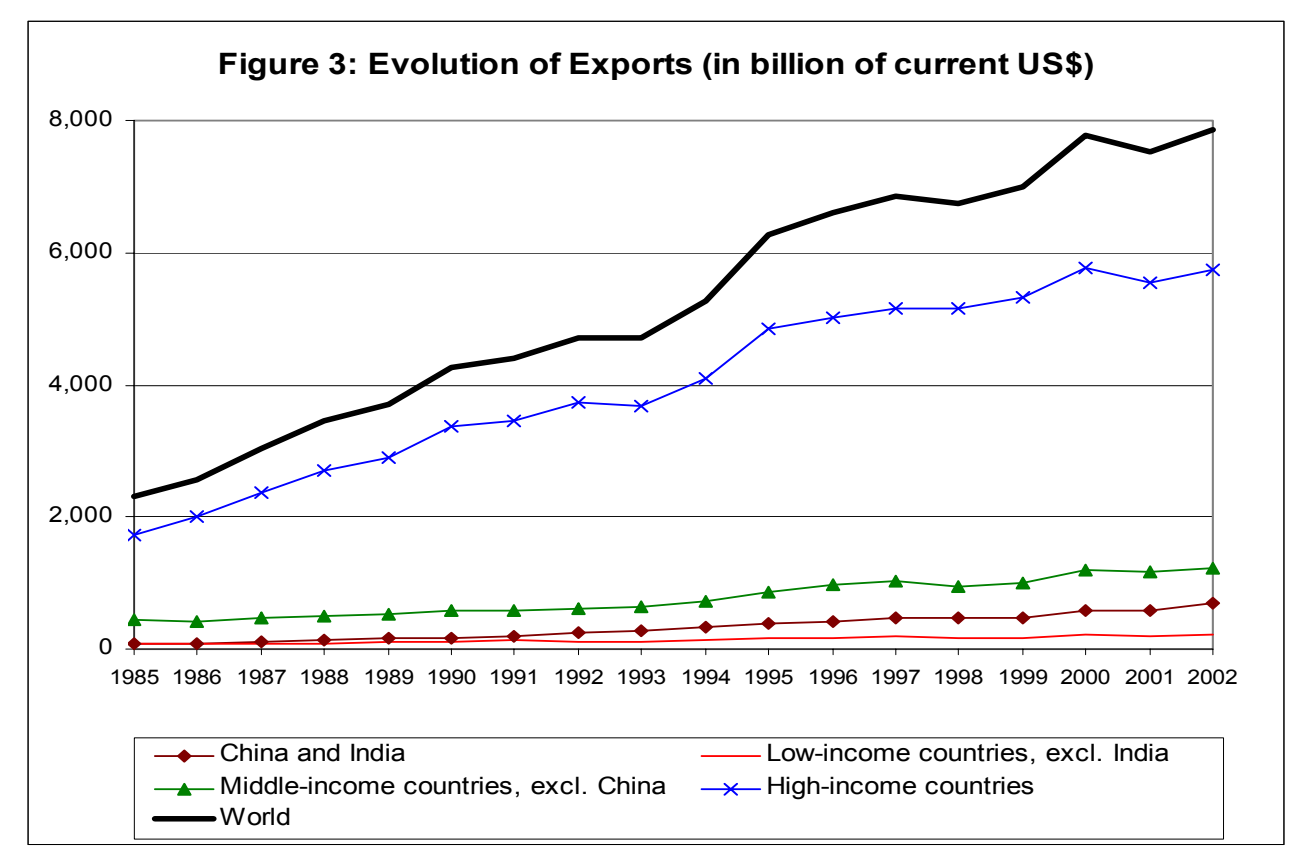

Source: Please see Table 1.

\subsection{International Capital}

In this section we look shortly at two main categories characterizing the globalization of international capital: foreign direct investment and portfolio investment. Foreign direct investment (FDI) is defined as investment that is made to acquire a lasting management interest (usually at least 10 percent of voting stock) in an enterprise operating in a country other than that of the investor's residence. Portfolio investments are usually shorter-term capital flows, defined as the sum of portfolio investment in equity and bonds. Portfolio equity investments consist of country funds, depository receipts, and direct purchases of shares by foreign investors.

\subsection{Foreign direct investment (FDI)}

Looking at the data for FDI from 1985 to 2002 (presented in Table 1 and graphically illustrated in Figure 4), we can see that today's world level of FDI inflows is with US $\$ 633$ billion more than 10 times its 1985 level (US\$58 billion). In absolute terms, all four groups experienced an overall increase during 1985-2002. However, in relative terms (defined as shares in world FDI), China and India increased their share from 2.9 percent in 1985 to 9.8 percent in 2002, the high income countries experienced a marginal decrease from 77.1 percent in 1985 to about 76.6 percent in 2002, while the low income countries (excluding India) and the middle income countries (excluding China) lost significant shares. The share of the low-income countries (excluding India) fell from an already marginal share of 3.3 percent in 1985 to 1.1 percent in 2002 while the middle-income countries excluding China decreased their share from 16.8 percent in 1985 to 12.5 percent in 2002. Clearly, most low- and middle-income countries have not received the FDI 
inflows they were hoping to receive, even though they had undertaken policy measures to attract foreign capital.

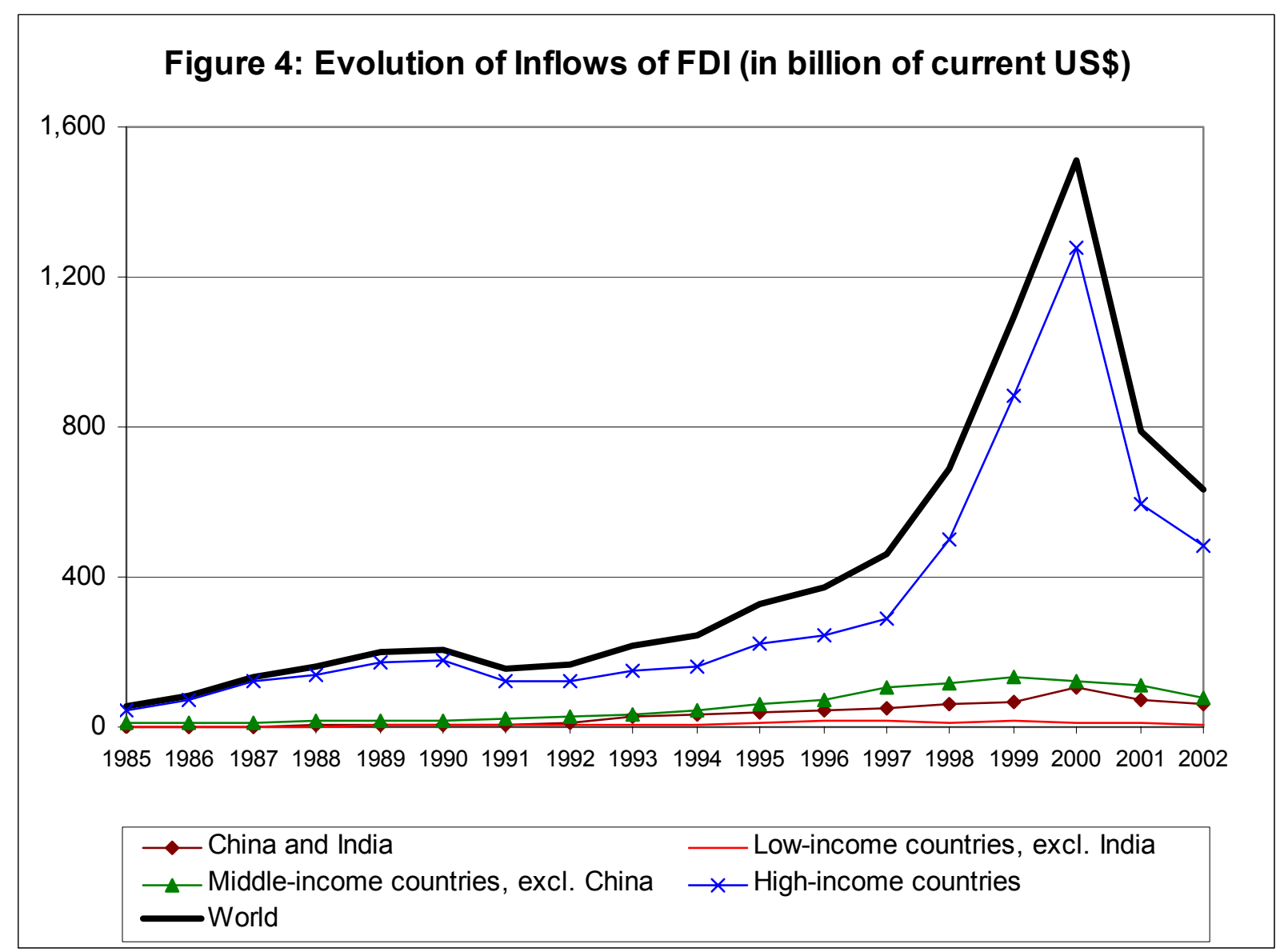

Source: Please see Table 1.

\subsubsection{Portfolio investment}

The size and evolution of portfolio investment flows (illustrated in Figure 5 and 6) show an even more alarming picture. First, the huge nominal differences in the levels of portfolio equity investment across income groups make it necessary to display the evolution of portfolio investment in two separate charts. Though Figure 5 shows the evolution for all four country-groups, the gross inflows of portfolio investment into high-income countries are more or less identical to the world level. Hence, Figure 6 provides the details of $\mathrm{s}$ the evolution for the low- and middle-income countries. 


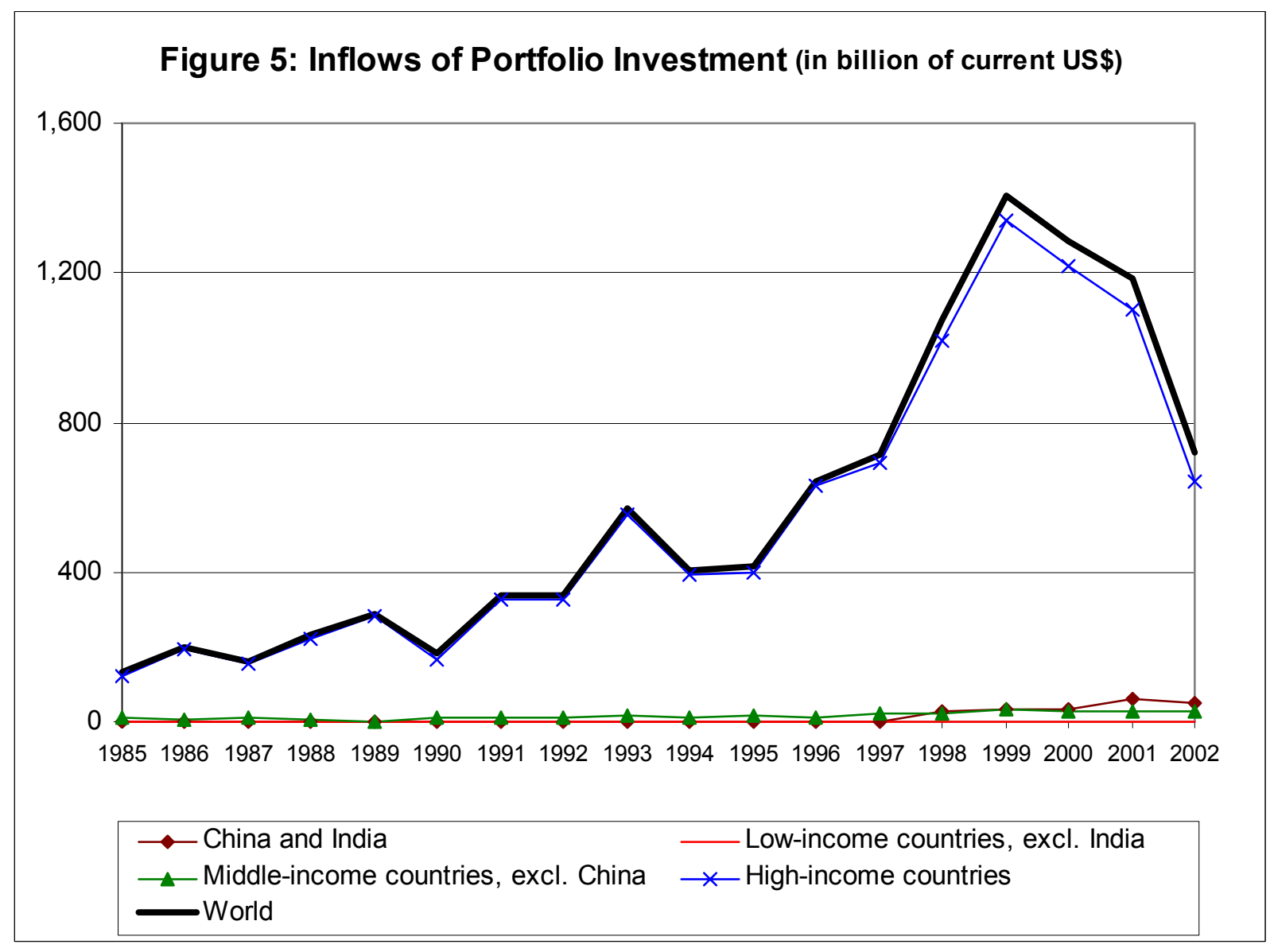

\section{Source: Please see Table 1.}

The salient facts are that (a) the high-income countries' share in world portfolio investment remains at around 90 percent, (b) the share of the low-income countries excluding India has decreased from around 0.04 percent to less than 0.01 percent, and (c) the share of the middle-income countries excluding India has decreased from 6.7 percent to 4.2 percent. As Figure 6 shows, even India and China did not play any significant role until the late 1990s. 


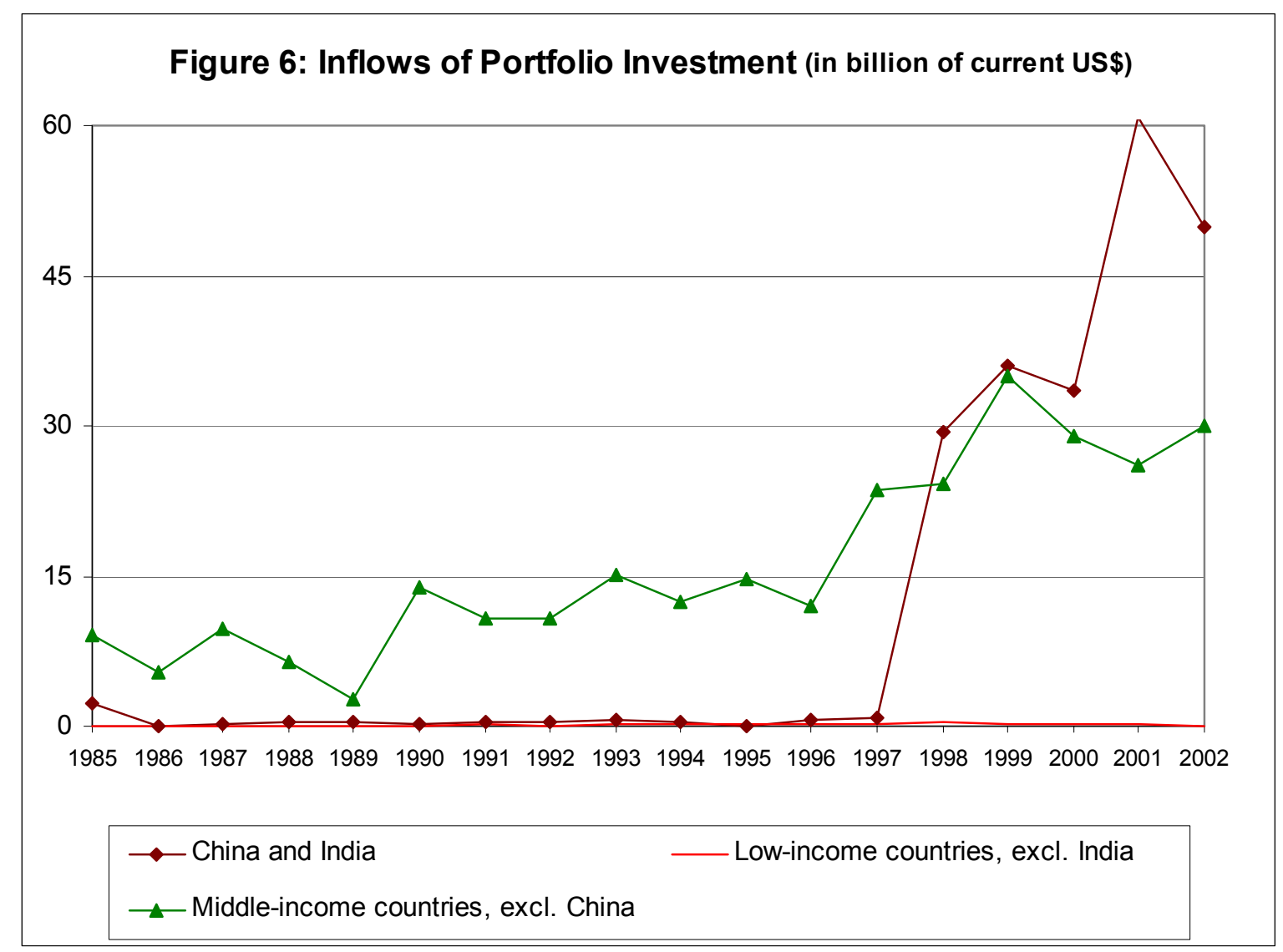

Source: Please see Table 1.

\subsection{International production}

The recent integration of international trade and finance has gone hand in hand with international production (also called fragmentation of production and/or intra-product specialization), which is the splitting of the production process into separate parts across national borders. It can be illustrated by looking at today's production of, for example, cars (automobiles). Though a car is typically assembled in one country, the various inputs (intermediate products) for the final assembly come from many countries. The intermediate products are likely to come from foreign-country plants, which are owned or at least partly owned by the same multinational corporation (MNC) that assembles the car. Indeed, all large car corporations have set up factories for intermediate car products in countries that are most profitable for the production of that specific intermediate product. In other cases, as for example pointed out by Barbara Emadi-Coffin (2002, page 165), the opening of markets has led to collusive behaviour between firms and the forming of strategic cross-border alliances such as joint ventures and product-sharing schemes. 
Though aggregate time series data on the fragmentation is scarce, the empirical literature (see section VI of the bibliography) allows us to characterize the fragmentation aspects of globalization as follows. First, more and more international trade appears to be in intermediate products. Second, over the last 15 years, we have also seen a wave of mergers and acquisitions, which led to powerful MNCs. Today, MNCs account for over two-thirds of world trade, and their share is even higher in trade of technologically advanced products. Third, while the developing countries' share of internationally fragmented products has remained stable over the last 15 years, the share of the low-income countries has decreased. To return to the example of today's car production, the vast majority of developing countries is not producing any car parts. As is the case with FDI, the international production within developing countries is highly concentrated among a couple of countries like Argentina, Brazil, China, Mexico, Singapore and Thailand. Most of the literature comes to the conclusion that the fragmentation of the production process across borders has been a driving force behind the intensification of international trade.

\section{The recent globalization process and its social dimension}

While most of the last section was based on statistical data that is largely undisputed, a considerable part of the literature analyzing the social impact of globalization is highly controversial. At the aggregate level, analyzing the overall social impact of globalization, most of the propositions fall within two polar views. For some, globalization has been an instrument for progress; it has created wealth, expanded opportunities and provided a nurturing environment for entrepreneurship and enterprise. For others, globalization has created unemployment, poverty, and marginalization and is thus seen as the institutionalization of social crises.

Given the huge literature analyzing the impact of increased international trade on labor costs and taxes, we first summarize the consensus that emerges in that respect, largely concluding that increased international trade led to considerable pressures on labor costs and wages. We then review the controversial debate on the impact of globalization on poverty. While the overall impact of globalization on poverty remains disputed, there is some broad agreement that globalization has exacerbated inequalities due to sharply diverging experiences at the individual level. We also review the impact of globalization on various aspects of inequality .Finally, we review the literature that looks, respectively, at the social impact of globalization on child labor, gender, and migration.

\subsection{Global Pressure on Wages and Employment}

Like any other profit-oriented business, MNCs base their decision on where to produce on the most competitive combination of (i) labor, (ii) technology, (iii) structural advantages, and (iv) the right business environment, which includes among others, low profit taxes and political stability. It is well documented that at least the 1990s saw an intensification of a competitive pressure to lower labor costs and taxes, especially in high- and middle-income countries. It is also well documented that much of the production in manufacturing had moved from industrialized countries to developing countries, though most developing countries have not yet been part of this shift in manufactured production. The shift in manufacturing production caused large-scale structural unemployment in the affected 
industries in most industrialized countries ${ }^{2}$ and a concurrent pressure to increase social protection, especially in state-sponsored unemployment insurance. Despite these demands, a decline in revenues resulting from lower tariffs and lower profit taxes, forced many governments to cut expenditure, including in the social sector, leading as argued by some to a dismantling and rethinking of the Continental European universalistic social security system. As researchers like Bob Deacon have pointed out, these pressures on the traditional welfare state have been seen as a threat to equitable social welfare states. ${ }^{3}$

While many of the detailed impacts of globalization on wages and employment remain highly controversial, there are two recent literature reviews on these issues. Greenaway and Nelson (2001) reviewed many of the major contributions to the literature on the labor market effects of globalization, covering the relationships between (a) trade and wages, (b) labor markets microstructure and adjustment, (c) trade and employment, (d) migration and labor market adjustment, and (d) foreign direct investment and labor markets. Greenaway and Nelson's review covers the major literature of the last twenty years, which looks predominantly at industrialized countries' experience. Rama (2003) reviewed the academic literature on the effects of globalization on workers in developing countries, including a description of the pattern of job destruction and job creation associated with globalization.

Most studies agree that Europe's initial resistance to cut wages and keep social protection more or less intact has led to high European unemployment but no significant changes in income distribution. On the other hand, the same competitive pressure has led to lower industrial wages and significant changes in income distribution in the United States, even though the United States imposed some "safeguard" measures to protect America from the negative impact of imports (see Stiglitz (2003)).

At the same time, globalization led to increased competition for the setup of new production plants within the group of developing countries. Nearly all developing countries have aimed at getting some share of the increased international production by establishing export process zones and making some concessions to MNCs, for example through tax exemptions and the public provision of infrastructure targeted to MNCs' demand. Thus, there also were large-scale structural changes in developing countries with considerable structural unemployment. While some of these costs have been compensated at the national level in those countries that were able to attract large-scale MNC investment (e.g., through the generation of new employment, including that of women and children), wages and jobs of the traditional work force have experienced considerable reductions. Overall, Freeman (2003) finds that the debate has exaggerated the effects of trade on economies and the labor market. Changes in trade policy have had modest impacts on labour market. ${ }^{4}$ Other aspects of globalization -- immigration, capital flows, and technology transfer -- have greater impacts, with volatile capital flows creating great risk for the well-being of workers. Freeman (2003) also concludes that global labour standards do not threaten the comparative advantage of developing countries nor do poor labor standards create a race to the bottom. Chau and Kanbur (2001) suggest that a Southern race to the bottom is possible but not inevitable.

2 However, as Stiglitz (2003) points out for the United States, although more and more manufacturing was being moved offshore, new high-paying jobs, largely in the service sectors, were created, which more than offset those lost in manufacturing (though obviously not all those previously employed in the manufacturing sector have been absorbed in the service sector).

${ }^{3}$ See Benvenisti and Nolte (2003) for a recent collection of papers on these issues.

${ }^{4}$ To a similar conclusion come Blom, Goldberg, Pavcnik, and Schady (2003). 
Ghose (2003) argues that 'there is really no evidence to suggest that expanding NorthSouth trade in manufactures has led to a competitive dilution of labour standards in either North or South'(p111), but points to a number of worrying developments of the which the foremost is the phenomenon of global exclusion ; a large number of developing countries, where $30 \%$ of the world's population lives, have become progressively marginal to the global economy and employment and labour standards have been declining in these countries. Other concerns are that trade liberalization has promoted non-beneficial integration into the global economy for some, mainly Latin American, economies and that globalization did not have a stimulating effect on global economic growth.

\subsection{Controversies of the impact of globalization on poverty}

While the vast majority of the academic and institutional literature concludes that globalization has spurred economic growth ${ }^{5}$ and that the overall benefits of globalization are larger than the overall costs, the literature assessing the impact of globalization on poverty is considerably more controversial. The more influential, mostly institutional literature concludes that globalization reduced poverty. However, many individual researchers have pointed out that the empirical analysis leading to that conclusion has a variety of conceptual flaws. ${ }^{6}$ The comprehensive study of Oxfam International (2002), popularizing that current trade rules and institutions are rigged in favour of developed nations, has shown that international trade can have both positive as well as negative impacts on poverty. The companion study of Oxfam America (2002), analysing the impact of private international finance on poverty, concluded that global finance hurts the poor.

The impact of global finance has been split up further into studies looking at various impacts of foreign direct investment (FDI) and of portfolio investments, whereby the majority of studies seem to assert that FDI is far more beneficial than other capital flows. Indeed, the sudden increase in short-term capital flows (largely invited by premature capital account liberalizations and large-scale short-term borrowing of financially troubled governments) have been asserted to hold a key responsibility for the various financial crises of the 1990s, and the subsequent social crises that reverted much of the progress achieved in previous years. Hence, the IMF, a traditional advocate of capital market liberalization has began to suggest that "financial integration should be approached cautiously, with good institutions and macroeconomic frameworks viewed as important."

\footnotetext{
${ }^{5}$ See the various contributions by Weisbrot et al. for a sharply opposing view, claiming that the recent globalization process has led to diminished progress and to lower growth than compared to growth of the 1970 s and 80 s.

${ }^{6}$ Of the large literature asserting a positive impact of globalization on poverty reduction, the World Bank's Policy Research Report (World Bank 2002), which is largely based on Dollar and Kraay (2001), is likely the most well-known. On the other hand, studies like Birdsall and Hamoudi (2002) and Nye, Reddy and Watkins (2002) asserted that there are various flaws in the World Bank's study likely leading to the wrong conclusion.
}

${ }^{7}$ See Prasad, Rogoff, Wen and Kose (2002), p. 5. 
The analytically and empirically outstanding study by Agenor (2002) examined the extent to which globalization affects the poor in low- and middle-income countries, whereby he stresses the possibility of a non-linear relationship. Using individual indicators of trade and financial openness as well as a globalization index based on principal component analysis to test for both linear and non-linear relationships between globalization and poverty, he concludes that the results suggest the existence of a non-monotonic, Laffer-type relationship between globalization and poverty. Interestingly, these cross-country results are consistent with the empirical data provided in section 2 of this paper, which showed that most of the low-income countries have been marginalized by the globalization process of the last 15 years. Furthermore, the results are also consistent with the consensus view of the impact of globalization on inequality.

\subsection{Globalization and Inequality}

It is now widely recognized that the benefits of growth depend crucially on the distribution of the income generated by economic progress. The functional distribution of income refers to the division of national income among the factors of production, traditionally identified as labour and capital. ${ }^{8}$ The size distribution measures the share of income received by individuals or families within certain income groups, traditionally identified by the share of total income that is received by different percentiles of the population. ${ }^{9}$

Nobel Prize economist Simon Kuznets (1901-1985) proposed a hypothesis in the mid-1950s that income inequality initially worsens as per capita GNP rises, peaking at intermediate income levels and declining for industrial countries. Kuznets' hypothesis is not only one of the most well-known, but also one of the most controversial hypothesis in economic theory. While there was some empirical support for the Kuznets inverted U curve for up to the 1960s, most re-examinations of the 1980s found little empirical evidence for such an inverse relationship. The debate has continued in the 1990s, with various studies coming to different conclusions about the relevance of the Kuznets curve. In any case, there is some general agreement today that growth and equity need not be contradictory goals. Most economists also agree that there is no automatic link between economic growth and equitable human development. However, when this link is forged with policy and determination, it can be mutually reinforcing and economic growth will reduce poverty and improve human development.

With regards to the impact of globalization on income inequality, there is now a large literature of more than 50 contributions, most of which comes to the conclusion that globalization has increased income inequality within a country as well as across countries (for example, Stiglitz (2003) argues that globalization, as it is actually practiced, tended to make poor societies more rather than less unequal). However, there is a strand of literature which questions these findings or arguing that while higher growth has come with increased inequality, poverty still decreases.

\footnotetext{
${ }^{8}$ It should be noted that the employee ownership of stocks has increased in most industrialized countries, leading to some blurring of lines between employees and employers. Yet, it is does not look like that this increased stock ownership has led to more labour-friendly management decisions.

${ }^{9}$ There a large number of ways of measuring inequality, for a list and description of the most commonly used measures, see: http://www.undp.org/poverty/initiatives/wider/wiid_measure.htm..
} 
There are various earlier studies that have separated between the impact of economic globalization (especially trade) and the impact of technological changes, mostly concluding that the main factor for the deteriorating income inequality is due more to technological changes than to globalization. However, Cornia and Court (2001) and Cornia and Kiiski (2001) have shown that the widespread surges in inequality are linked to excessively liberal economic policy regimes and the way in which economic reform policies have been carried out.

Cornia and Kiiski (2001) review the changes in within-country inequality over the last 20 years on the basis of an extensive review of the literature and on an analysis of inequality trends in 73 countries accounting for over four-fifths of world population and GDP. They find that inequality rose in two-thirds of these 73 countries over the last two decades, which marks a clear departure from the inequality trends recorded since the end of the Second World War. The paper also suggests that, with the exception of growing educational dispersion in Latin America, traditional causes of inequality (such as land concentration and urban bias) cannot explain the recent rise in income inequality. The latter appears to be related to a shift towards skills-intensive technologies, and especially, to the drive towards domestic deregulation and external liberalization. Of the six main components of this new paradigm, capital account liberalization appears to have had the strongest disequalizing effect, followed by domestic financial liberalization, labour market deregulation and tax reform. Privatization was found to be associated with rising inequality in some regions but not others, while trade liberalization had insignificant or mildly disequalizing effects.

Similarly, Singh and Dhumale (2000) indicate that with respect to developing countries, neither trade nor technology are necessarily the most important factors in increasing income inequality, though they agree that globalization (in the form of financial liberalization rather than trade) and technology are both likely to be significant factors in accounting for the increased inequality in developing countries during the last two decades. For developing countries, they conclude that the more relevant factors are social norms, labour market institutions such as unions and minimum wages, and macroeconomic conditions.

Khan, Griffin, and Riskin (1999), analysing the changes in recent income distribution in urban China concluded that increased income inequality has been more likely due to economic reform policies, especially cuts in the provision of social protection than to globalization, and that at least in the more prospering regions, globalization had - through the creation of new jobs - a positive impact on a more equal distribution on income. Hence, there may be some cases where the impact on income inequality can be derived from the Heckscher-Ohlin model, however, the overall consensus remains that globalization has led to increased income distribution within, as well as across, countries as long as we consider technological changes to be part of the globalization process.

Looking at the longer term perspective, there is some agreement that income distribution has deteriorated considerably during the twentieth century. According to the IMF (2000), the world Gini coefficient has risen from 0.40 in 1900 to 0.48 in 2000. Bourguignon and Morrisson (2002) show that most of the divergence in income distribution among world citizens seems to have occurred in the first half of the twentieth century. However, we should keep in mind that Bourguignon and Morrisson's study ends with 1992, the experience since then seems to be again deteriorating. 
Burtless (2002) has argued that income may not be the best indicator to assess the impact of globalization on inequality, and that looking at indicators like life expectancy would show that globalization had an equalizing impact. On the other hand, there is some indication that due to the AIDS epidemic, disparities in life expectancy are once again growing. Furthermore, the earlier periods of improvements in life expectancy may be influenced by the spread of medical advancements. Finally, life expectancy may not necessarily be a better indicator to assess the impact of globalization on inequality than income, especially as qualitative factors of life are not taken into account by looking only at life expectancy.

\subsection{Augmented global insecurity}

There are many ways to define insecurity, to mention some: job insecurity, lack of social protection, food insecurity, and fear of terrorism. No matter how we define insecurity, there is a broad consensus in the globalization literature that globalization has increased economic, social, and political insecurity, even for those who have benefited from globalization.

The most extensive coverage of issues related to job insecurity and changes in employment patterns is provided in Torres (2001). The broader issues related to economic insecurity among workers are the subject of a recent empirical study by Scheve and Slaughter $(2002)^{10}$ and various contributions in a book edited by Debrah and Smith (2002). Globalization and food security are addressed in Davis, Thomas and Amponsah (2001). The link between globalization and terrorism has (among others) been made in World Bank (2002).

While the heightened international volatility of trade, capital flows, and production has contributed to this negative impact of globalization, it is also clear that the lack of political actions to counter the heightened risk and uncertainty has contributed equally if not more to increased global insecurity. Assuming that people are usually risk averse, the more difficult question is if the costs due to increased insecurity have been more than compensated by the overall benefits of globalization. This is likely to be answered in the affirmative for workers and families that have been lifted out of poverty due to globalization, however, like as is the case with many other aspects of globalization, the literature seems to conclude that the poor and disadvantaged pay an unproportional share of the increase in insecurity, largely due to market failures that prevent them to properly smooth income and consumption.

In conclusion, globalization has increased insecurity, increased insecurity aggravates the negative implications of rising inequality, and - as Kaplinsky (2001) and others have argued - the combination of increased insecurity and increased inequality is so widespread that it threatens the sustainability of the current globalization process.

10 Scheve and Slaughter (2002) pointed out that the common claim that economic integration increases worker insecurity lacks empirical verification. They argued that economic insecurity among workers may be related to riskier employment and/or wage outcomes, and that foreign direct investment may be a key factor contributing to this increased risk by making labour demands more elastic. 


\subsection{Globalization and child labour}

When reviewing the literature on the impacts of globalization on child labour, it is possible to distinguish three trends. The first trend of child-labour-related literature alerted the public of the severe negative impacts globalization had on child labour in specific countries and specific industries. A second trend of the literature concentrated on the debate over the usefulness of industrialized countries' legislation, e.g., to boycott child labour manufactured products, and the appropriateness of integrating industrialized countries' standards into international trade negotiations. A third trend provides some empirical evidence on the impact of globalization on child labour and takes a much wider view of the impact of globalization on children. ${ }^{11}$

The following conclusions on the social impact of globalization on child labour are largely based on the third trend of the literature. First, while the initial conclusion was that globalization has increased child labour activities, we know today that this had been due largely to an initial shift of child labour from informal home and family enterprises into more visible and formal wage-employment. Second, while there obviously have been unacceptable abuses, some of this formal child labour had positive short-term effects on poor families' income. Third, due to international pressure and the fear of developing countries that industrialized countries may boycott the import of products manufactured with child labour, most developing countries have adopted restrictive child labour legislation. Some MNCs have also voluntarily eliminated child labour due to public pressure in industrialized countries. Though there remain severe lacks in the enforcement of the legislation adopted by developing countries, the recent empirical literature ${ }^{12}$ comes to the conclusion that globalization has actually reduced child labour, at least in the formal sector. It is not so clear how beneficial this reduction in formal child labour was. Based on a critical review (including the results of an ILO/UNICEF study that analysed the impact of the 1993 dismissal of child workers in the Bangladeshi garment industry), White (1996) concludes that the overriding aim should be to combat the exploitation of children, rather than to exclude them from the labour market.

\subsection{Globalization and gender}

The literature analysing the impact of globalization on gender covers a variety of controversial aspects and remains overall inconclusive. While there was some tendency in the initial literature to conclude that globalization might have reduced gender imbalances, largely due to increases in female participation rates, the more recent literature tends to show that the discrimination against women nevertheless continues. Comparing the gender literature with that on child labour, the common initial trend has been that both, women and children have become more integrated into formal employment. The difference is that in the case of child labour, the increased participation rate of children had been considered to be detrimental for children, while the increased participation of women has been considered to be beneficial for women. There certainly has been some progress in the social status of women, based on the fact that the female participation rate has increased,

${ }^{11}$ With regards to the latter, see especially Cornia (2002), who examines also complementary policies and programmes, like social insurance, childcare and family support, that can best harness children's benefits of globalization.

\footnotetext{
${ }^{12}$ See Cigno, Rosati and Guarcello (2002) and Edmonds and Pavcnik (2002).
} 
especially in manufacturing and export product zones. However, some of the more recent studies, see especially the review paper by Chambers (2000), ${ }^{13}$ have argued that despite the increase in female participation rates, women remain economically disempowered. Indeed, one of the reasons for the increase in female participation is due to the fact that women accepted lower wages. Furthermore, it has also been argued that many female workers have little control over the spending of their salary, and that the key responsibility for unpaid household and family work remains with women, some times even in households where women provide the main or only income. Some studies have also stated that in some instances, violence and hostility of men against women has increased due to the change in social status of women.

The following conclusions provide an overview of the variety of issues addressed in the most recent literature analysing the impact of globalization on gender. Black and Brainard (2002) conclude that "increased competition through trade did contribute to the relative improvement in female wages in concentrated relative to competitive industries, suggesting that, at least in this sense, trade may benefit women by reducing firms' ability to discriminate". On the other hand, Balakrishnan (2002) concludes that the international fragmentation of production has led to the flexibilization of work and that women often accept unstable and vulnerable work in order to incorporate their reproductive role with paid work. Similarly, Moghadam (2001) casts a gender perspective on globalization to illuminate the contradictory effects on women workers and on women's activism. She concludes that globalization has had dire economic effects on women; however, the process has created a new constituency of working and organizing women, which may herald a potent anti-systemic movement.

Carol and Vivian (2002) argue that the current emphasis on trade liberalization and economic restructuring will affect many countries that have a large female workforce in labour-intensive industries; that increased competitiveness must come in large part from technological upgrading and increasing labour productivity; and that there is a challenge to make the transition to high-wage, high-productivity employment without substituting the existing female workforce, that is drawn from lower income households with male workers and more socially privileged workers. Finally, the principal conclusions that emerge from Çağatay (2001) are:

[...] that men and women are affected differently by trade policies and performance, owing to their different locations and command over resources within the economy; that gender-based inequalities impact differently on trade policy outcomes, depending on the type of economy and sectors, with the result that trade liberalization policies may not yield expected results; and that gender analysis is essential to the formulation of trade policies that enhance rather than hinder gender equality and human development.

\footnotetext{
${ }^{13}$ Chambers (2000) is the Background Paper to the 2001 DFID White Paper on Eliminating World
} Poverty: Making Globalization Work for the Poor. 


\subsection{Globalization and migration}

When reviewing the impact of globalization on migration, the first observation is that the recent globalization process has led to far less international migration than any time else in world history. There is also no doubt that the limited migration is mostly due to constraints set in industrialized countries' immigration laws. Thus, compared to earlier large-scale migrations, today's migration process is far more selective in terms of both emigration and immigration countries. Stalker's (2000) comprehensive analysis, summarized in Stalker and Perraton (2001), concluded in this regard that some of the traditional migration channels, particularly from Europe, have dried up, while many new ones are being created, notably in South-East Asia. The World Development Report 1995 has shown that today's migrants increasingly come from poor countries. ${ }^{14}$

Second, as for example, Solimano (2001) has pointed out, today's globalization process is less friendly to the international migration of unskilled people than were previous waves of globalization. This last aspect of migration is long known and commonly referred to as "brain drain". There is broad agreement that emigration has a considerably negative impact on labour supply in some developing countries, especially as most of the emigrants are part of the most productive and most educated labour supply.

On the other hand, sending countries benefit from migration due to remittances migrants send back to their country of origin. The World Development Report 1995 declared that remittances represent between 10 and 15 per cent of GNP in Jordan, Lesotho, Yemen, and the West Bank and Gaza, and between 25 to 50 per cent of exports in Bangladesh, Burkina Faso, Egypt, Greece, Jamaica, Malawi, Morocco, Pakistan, Portugal, Sri Lanka, Sudan, and Turkey. Though these remittances improve the living standards of the receiving families, they contribute little to the sending countries' development, and thus, the migration of the most educated and most productive workers remains a problem, especially in the poorest countries.

${ }^{14}$ Data from Pakistan indicate that about 25 per cent of the incremental labour supply have left the country during 1978-1983. 
A variety of issues concentrating on the migration of people in a global economy are also addressed in three contributions in the book edited by Baker, Epstein, and Pollin (1998). ${ }^{15}$

There is some tentative conclusion (see Nayyar 2002), that the time has come to initiate a preparatory process which would work towards a new institutional framework that would govern cross-border movements of people. We will return to this in more details in the next section.

\section{National and international policy responses}

There is no dearth of suggestions for policy responses in the recent literature. These range from calls for protectionist policy measures to changes in national education plans and include also the creation of new international organizations. We first provide a short overview of the broad policy suggestions emphasizing the role of the state and complementarities between actors and policies, and then review some selective national and key international policy actions in more detail as discussed in the literature.

\subsection{Overview of policy responses}

The literature on comprehensive policy responses to globalization( in contrast to single responses like protectionism) is relatively new and came in the wake of the vast literature on structural adjustment programmes, which reviewed how issues like trade liberalization, debtrelief,and national economic reform isuues like market liberalization and privatization affected growth and poverty. After the eruption of the Asian crisis in 1997,public and academic opinion became more concerned with policy actions to either prevent and/or reduce the negative effects of globalization, Lee(1998). In addition, it has been suggested that the returns from globalization and their distribution can be improved through an appropriate mix of policy measures. This is comprehensively outlined in ECLAC (2002), Khor (2001), Ocampo and Martin (2003), Torres (2001), and World Bank (2002). UNCTAD (1996) also provided ten broad recommendations, based on 14 inter-agency contributions, analyzing the effects of globalization (especially liberalization) on poverty.

\footnotetext{
${ }^{15}$ Quoting the Introduction of the three editors: "Sutcliffe's paper frames the issue boldly with his argument that, as a matter of principle, international borders should be open." While recognizing that this is a utopian perspective in the current environment, Sutcliffe argues that a clear policy approach flows from his principled position: first, that borders should be open to the maximum extent, and second, that the rights of immigrants in host countries should be broadened. He further argues that the absence of principled perspectives in Western Europe has been a major factor poisoning attitudes toward migrants there. Gregory De Freitas' contribution focuses on the practical constraints on immigration in the United States and, in particular, the impact of increased migration on the United States labour markets and the public sector. The third paper by Prabhat Patnaik and C.P. Chandrasekhar focuses on the effects of emigration of less skilled workers in developing economies, which according to the authors produces unequivocally beneficial effects for the sending country.
} 
Torres (2001) provides the synthesis of seven country-specific studies on the social impact of globalization (Bangladesh, Chile, the Republic of Korea, Mauritius, Poland, South Africa, and Switzerland) and suggests a variety of policy actions related to: (a) enhancing business opportunities arising from globalization; and (b) the strengthening of the four social pillars (education and training, social safety nets, labour laws, and core labour standards), which as Torres points out, are not only important in itself, but can also contribute to improving the gains from globalization.

Khor (2001) suggests a variety of lessons to be learned from the experiences of liberalization throughout the book, and provides more general proposals in the concluding chapter, including the balancing of opportunities and problems resulting from globalization, the need for South-South policy coordination among developing countries, the need for appropriate and democratic global governance, a rebalancing of the roles of state and market, and finally, a search for appropriate development strategies.

While stressing repeatedly that globalization has been a force for poverty reduction, the World Bank's Policy Research Report on Globalization, Growth, and Poverty emphasizes seven policy action programmes which the authors of the report see as particularly important for making globalization work for the poor: (a) a "development round" of trade negotiations; (b) improving the investment climate in developing countries; (c) good delivery of education and health services; (d) the provision of social protection tailored to the more dynamic labour market in an open economy; (e) a greater volume and better managed foreign aid; (f) additional debt relief; and (g) the tackling of greenhouse gases and global warming.

Ocampo and Martin (2003) as well as the recent ECLAC (2002) report on Globalization and Development decribe extensively policy actions covering (a) four fundamental principles for the construction of a better global order, (b) five national strategies for dealing with globalization, (c) the key role of action at the regional level, and (d) six more specific global agendas. The four fundamental principles address three key objectives ${ }^{16}$ global rules and institutions that respect diversity, the complementarity of global, regional and national institution-building, and the equitable participation and appropriate governance. The five national strategies suggested for dealing with globalization refer to (i) the role and basic composition of national strategies, (ii) the macroeconomic strategy, (iii) the building of systemic competitiveness, (iv) aspects of environmental sustainability, and (v) a variety of social strategies. The global agendas address (i) global macroeconomic public goods, (ii) sustainable development as a global public good, (iii) the correction of financial and macroeconomic asymmetries, (iv) the overcoming of production and technological asymmetries, (v) the full inclusion of migration on the international agenda, and (vi) the establishment of economic, social and cultural rights as the foundations for global citizenship.

Whereas the Asian crisis triggered off a wide set of literature, there have been a couple of key publications prior to the Asian crisis that have called the until then nearly unchallenged globalization process into question: Boyer and Drache (1996), Deacon (1997), Geider (1997), Gill (1997), Hart and Prakash (1997), Mittelman (1996), Rodrik (1997), Siebert (1997), and UNCTAD (1996). While many more critical contributions have been published since 1997, it is fair to say that few of those suggestions have been implemented. In addition to the contributions already mentioned above, and excluding the

\footnotetext{
16 The three key objectives are the supply of global public goods, the correction of international
} asymmetries, and the establishment of a rights-based global social agenda. 
specific recommendations made in the large literature on labor issues, ${ }^{17}$ comprehensive policy actions have recently also been suggested by Eichengreen (2002), Masson (2001), and Murshed (2002). Juxta posing the pre- and post-Asian crises literature a general one of the general conclusions is that more action needs to be taken to avoid further social unrest, which as Bourguignon et al. (2002) have pointed out, could destroy many of the real gains that globalization has achieved.

While there is some agreement that globalization has reduced the autonomy of the nation state in economic matters, there is now also agreement that globalization calls for increased state "activity" in social matters; see for example, the extensive discussions in Chang (2003),Nayyar (2001) and Woolcock (2001). In other words, the reduced role of the State in economic matters needs to be complemented by an increased role of the State in social matters. Indeed, there is agreement that the state has an important role to play. There are however controversies on what exactly the State should or should not do, through which instrument, and how to finance the policy action (e.g., through user fees or taxes).

Furthermore, while globalization requires some homogenization of policies, there are many areas where differences in national standards need to be respected and the imposition of international standards could be more harmful than helpful for making globalization more inclusive and more effective. Murshed (2000) provides a useful discussion of this issue related to environmental and labour standards; the importance of core labour standards is addressed in more details below.

In deciding on who should act, the principle of subsidiarity is key, whereby many different actors could be considered: individuals; families; businesses; unions; States; and all kind of organizations (including non-governmental organizations, regional development institutions, and global institutions). The recent ECLAC (2002) report on Globalization and Development provides a detailed discussion of the complementarity of global, regional and national institution-building. In many cases, there will be some complementarity between various actors, which with proper coordination could mutually enforce individual actions.

Finally, besides complementarities between actors, there are of course also complementarities of policy actions within an actor. Most of the recent national and international policy suggestions to achieve growth and to reduce poverty imply policy actions that will make globalization a more equitable and sustainable process. Subsequently, the following national and international policy actions should not be understood as an exhaustive list, but as a selective list of policy actions that have been closely related to globalization.

\footnotetext{
${ }^{17}$ With regards to the many suggestions made in the huge literature on labor issue, see Greenaway and Nelson (2001), Lee (2000), Memedovic, Kuyvenhoeven, and Molle (1998), Rama (2003), Stiglitz (2002), and van der Hoeven and Taylor (2000). Rama (2003, pp. 22) cautions, "the most effective ways to mitigate the adverse effects of globalization are probably out of the labor market." For suggestions specific to gender and labor markets, see Tzannatos (1999).
} 


\subsection{Selective national policy responses}

Given that countries are at different stages, have different institutions, and different priorities, national policy responses will vary from country to country. However, there are some national policy actions, which apply to all governments and have received attention in the recent globalization literature: (a) the investment in education and training; (b) the adoption of core labour standards; (c) the provision and improvement of social protection; (d) the tackling of rising national inequality; and (e) the provision of space to discuss globalization. There are many more policies that are gaining importance in an increasingly globalized world: sustainable macroeconomic policies, policies that promote a sound investment climate, prudent financial regulations, and a variety of sector specific policies. We refer to the extensive traditional economic literature for further discussion of these policies.

\subsubsection{Investing in education and training}

There is broad agreement that the most rewarding policy action is related to investments in education and training, including the upgrading of policies and institutions that manage innovations. While the poorest countries may concentrate initially on the provision of free basic education (complemented by free basic health services, like immunizations), middle-and high-income countries may need to adjust their education curriculum. Given that globalization leads to considerable structural unemployment, it would also be important to provide targeted training to the unemployed, which would allow them to switch to professions for which there is more demand. Recent experience has shown that the goal towards universal primary education may require that families from the poorest segments of society are compensated for their loss in income due to sending children to school. The importance of education and training and related issues is described and discussed in more detail in ECLAC (2002, pages 108-109), Eichengreen (2002, pages 2229), Torres (2001, pages 54-56), UNCTAD (1996, pages 18-19), and World Bank (2002, pages 156-157).

\subsubsection{Adopting core labour standards}

There is now also broad agreement that the adoption of the four core labor standards (elimination of child labor, the abolition of forced labor, encouraging non-discrimination in employment, and freedom of association and collective action) is a highly effective policy action to make globalization more equitable, though it needs to be stressed that differences in national definitions (e.g. of what constitutes child labor) need to be respected. In most cases, the adoption of each core labor standard calls for complementary policy action, like the compensation of income losses from child labor already mentioned above. Issues related to core labor standards are described in more details in Torres (2001, pp. 63-66), as well as in many other contributions going back at least until the mid-1990s.). ${ }^{18}$

${ }^{18}$ See Freeman (1998), Maskus (1997), OECD (1995 and 1996), Rodrik (1996), and Srinivasan (1994). 


\subsubsection{Providing and improving social protection}

There is some agreement among the academic literature that - based on the negative social impacts of globalization - more effective social protection systems are needed. The problem is that there are large differences on what constitutes an effective social protection and how to finance it. Fact is, that globalization has contributed (among many other factors) to the dismantling of some aspects of social protection and social insurance, especially with regards to social protection models based on universal coverage and large government expenditures in industrial countries. While some call for the full restoration of the classical model, others prefer new models based on private contributions and private management. The most comprehensive recent contributions linking globalization to social policy are Deacon (2000b, 2001a, and 2002a), Gough (2001), Norton (2000), Norton and Conlin (2000), and Yeates (2001 and 2002). With regards to the provision of effective unemployment insurance, it has been suggested that one of the most complementary policy action is to deliver active labour market programs.

\subsubsection{Addressing increasing national income inequality}

While the three pervious policy actions are likely to contribute to making globalization a more equitable process, pressure is building to also use policy actions to directly address increasing national income inequality. One of the strongest arguments for such direct measures is based on results of the recent literature, coming to the conclusion that the poverty elasticity of growth is higher in more egalitarian societies. Cornia (2004) provides a detailed discussion on what policies might be used to reduce inequality. Furthermore, there are a variety of complementary labour market policies, which can be very effective to reduce inequality (van der Hoeven and Saget 2004).

\subsubsection{Providing space for discussing globalization}

Finally, a relatively simple and costless policy action would be to provide space for discussing globalization. In developing countries, this could be part of the consultation process already under way with the formulation of Poverty Reduction Strategy Papers (PRSPs). In most other countries, such space could easily be provided by the grassroots networks most political parties have, and then feed back into the political decision making process.

\section{International policy responses}

While there have been many suggestions for international policy responses including some which can be traced back before the discussion on the current wave of globalization took off, such as the reform of the IFIs and the UN, increases in development aid, debt relief, international taxes and tax coordination, there are only two sets of policy actions, which have received broad support in the globalization literature: (a) a development round of trade negotiations and (b) a new financial architecture. Yet, both still face a variety of political opposition before they can be implemented. 
Reflecting the increasingly unfair rules in the area of international trade, there have been widespread calls for a development round of trade negations. The issues of (a) industrialized countries' trade restrictions for developing countries' agricultural goods, combined with industrialized countries' subsidies on their domestically produced agricultural products, and (b) the issue of intellectual property rights on urgently needed medication to fight AIDS are probably the most well-known concrete issues in the area of trade. At a broader level, Rodrik (2001) has suggested that the focus needs to shift from promoting liberalization to fostering development. As the current setback in WTO trade negotiations shows, many developing countries are not convinced that further extensions of the WTO's authority-into issues that go far beyond traditional trade-will be beneficial to them. In addition to various suggestions to improve the developing countries' negotiations capacity, suggestion have also been made to make revisions in the WTO's single undertaking mandate and in the WTO's consensus building process. Hence, bilateral trade agreements have been rising even though they are second-best solutions, especially if they are pushed onto developing countries with the promise of other benefits.

\subsection{A new financial architecture}

Reflecting the increasingly unfair rules in the area of international trade, there have been widespread calls for a development round of trade negations. The issues of (a) industrialized countries' trade restrictions for developing countries' agricultural goods, combined with industrialized countries' subsidies on their domestically produced agricultural products, and (b) the issue of intellectual property rights on urgently needed medication to fight AIDS are probably the most well-known concrete issues in the area of trade. At a broader level, Rodrik (2001) has suggested that the focus needs to shift from promoting liberalization to fostering development. As the current setback in WTO trade negotiations shows, many developing countries are not convinced that further extensions of the WTO's authority - into issues that go far beyond traditional trade-will be beneficial to them. In addition to various suggestions to improve the developing countries' negotiations capacity, suggestion have also been made to make revisions in the WTO's single undertaking mandate and in the WTO's consensus building process. Hence, bilateral trade agreements have been rising even though they are second-best solutions, especially if they are pushed onto developing countries with the promise of other benefits.

\subsection{Second-generation proposals}

In addition to the many institution-specific suggestions on the role of the UN system, the ILO, the IMF and the World Bank, ${ }^{19}$ there is a variety of so called second-generation proposals which were proposed before the discussion on globalization gained momentum. Many of such proposals have regained some attention in the recent literature, but lack sufficient political support, at least until now. To this group belong (a) a variety of reform proposals of existing international institutions, whereby the calls for changes in the governance structure of the World Bank and IMF are currently popular, ${ }^{20}$ (b) the creation of new international organizations, (c) the integration of social goals into international agreements, (d) the tackling of global inequality through international taxation, and (e) a variety of issues related to international migration. The most detailed elaboration on these second-generation proposals can be found in Nayyar (2002). There have of course also

${ }^{19}$ For example, see Gudgeon (2001), Hagen (2003), Köhler (2003), and Wolfensohn (2001 and 2003).

${ }^{20}$ See Buira $(2002,2003)$ and Jacobs (2002). 
been many mostly unsuccessful attempts to shift global policy from its neoliberal character to something more socially responsible. Consequently, Deacon (2003) suggested that it might be more useful to shift the focus of improving the world's management of global social issues toward networks, partnerships and projects.

\subsection{Policy actions that require international agreements}

Finally, there are also many policy suggestions of policy actions that can only be addressed effectively through international agreements. Some of these reform proposals are not directly related to the recent globalization process, to mention a few examples: (a) calls for the provision of more and better managed foreign aid, (b) the need for more debt relief to the poorest and highly indebted countries, and (c) the various environmental policy suggestions, like the tackling of greenhouse gases and global warming. To the degree that there are gaps in the global governance system to address these issues effectively, new international organizations may be needed. Recent collections of papers addressing such issues of global governance can be found in Siebert (2003) as well as in McCann and McCloskey (2003).

\section{Conclusions}

The key economic aspects of the globalization process of the last 15 years are characterized by:

- a more than three-fold increase in international trade, though the share of lowincome countries' share in world trade has decreased considerably,

- a more than 20-fold increase in FDI across the world, though the low-income countries' share in world FDI has decreased drastically,

- $\quad$ a more than 20-fold increase in portfolio equity investment across the world, though the low-income countries' share (excluding India) remains to be close to zero, and

- $\quad$ an increased fragmentation of production, whereby the share of developing countries in international production is decreasing.

Considering the vast literature on globalization we notice that the social impact of globalization on poverty, child labor, gender, and migration remains controversial, but we see a consensus to emerge that globalization has (a) overall more benefits than costs, (b) exacerbated inequalities within countries as well as across countries due to sharply diverging experiences at the individual and country level, and (c) increased economic and political insecurity even for those who have benefited in monetary terms from globalization. Yet, making causal links between changes in poverty and inequality with increased economic globalization remains a challenge as today's globalization process goes far beyond economic aspects, and is increasingly influenced by global health and environmental crises (like AIDS and climate changes). However, even if globalization may not have been the major cause of income inequality and poverty, it is likely to have contributed to the poor performance in terms of poverty reduction, see Kohl (2003).

As Stiglitz (2003) has put it, though globalization had often not produced the benefits that were promised, the issue is not whether globalization can be a force for good which benefits the poor of the world (which it can of course be), but that globalization needs to be managed in the right way and too often it has not been.. As we documented, most of the details with regards to the size, implementation, and financing of national and international policy actions to manage the process of globalization remain controversial. However, some consensus in the literature seems to emerge indicating that that national governments need to (a) invest in education and training, (b) adopt core labor standards, (c) provide and improve social protection, (d) tackle rising national inequality, and (e) provide space to 
discuss globalization. At the international level, there two sets of policy actions, which have received broad support in the globalization literature are: (a) a development round of trade negotiations and (b) a new financial architecture. It will require much more discussion and research at national and international levels to make globalization a socially more sustainable process. Too many people still live in conditions that are unacceptable for the $21^{\text {st }}$ century. A beginning has been made and building on the cooperation of the wide variety of agents active in the increasingly globalized world ${ }^{21}$ as well as including those that have thus far been marginalized or excluded, there is some hope for the future. Yet, as Storm and Naastepad (2001) have put it, development will not happen by globalization alone.

${ }^{21}$ For example, building on the work of the World Commission on the Social Dimension of Globalization, labor ministers of the Group of Eight (G-8) have called for the creation of a forum for dialogue on social issues which would include the ILO, the UN Trade and Development Conference, the WTO, the World Bank and the IMF (see La Tribune of December 17, 2003). 


\section{Bibliography}

Adams, Richard H. Jr. and John Page (2003), International migration, remittances, and poverty in developing countries, World Bank, Policy Research Working Paper, No. 3179 (December).

Adams, Richard H. Jr., (2003), International migration, remittances, and the brain drain: a study of 24 labor-exporting countries, World Bank, Policy Research Working Paper, No. 3069 (May).

Agénor, Pierre-Richard (2002), Does globalization hurt the poor? World Bank, Policy Research Working Paper, No. 2922 (October).

Akyüz, Yilmaz (ed.) (2002), Reforming the Global Financial Architecture: Issues and Proposals, Geneva: UNTAD; Penang: Third World Network; and London: Zed Books.

Anker, Richard, Rajenda Paratian and Raymond Torres (2001), Mauritius (Studies on the social dimensions of globalization), Geneva: International Labour Office.

Baker, Dean, Gerald Epstein and Robert Pollin (eds.) (1999), Globalization and progressive economic policy, Cambridge; New York: Cambridge University Press.

Balakrishnan, Radhika (ed.) (2002), The hidden assembly line: gender dynamics of subcontracted work in a global economy, Bloomfield, CT: Kumarian Press.

Becker, Gary S., Tomas J. Philipson, and Rodrigo R. Soares (2003), The quantity and quality of life and the evolution of world inequality, National Bureau of Economic Research (NBER), Working Paper, No. 9765 (June).

Benvenisti, Eyal and Georg Nolte (eds.) (2003), The welfare state, globalization, and international law, Berlin and New York: Springer.

Bielenstein, Dieter (2002), The social dimension of globalization: a critical assessment by civil society, Friedrich Ebert Stiftung, Dialogue on Globalization, Conference Report of the Asian Regional Conference at Thammasut University, Bangkok (December 17-18, 2002). Available at: http://fes.globalization.thinkvisually.de/pubDriver/clients/fesDog/attachments/020101 01_Bang.pdf

Birdsall, Nancy and Amar Hamoudi (2002), Commodity dependence, trade, and growth: when "openness" is not enough, Washington, DC: Center for Global Development, Working Paper, No. 7 (May). Available at: http://www.cgdev.org/wp/cgd_wp007.pdf.

Black, Sandra E. and Elizabeth Brainerd (2002), Importing equality? The impact of globalization on gender discrimination, National Bureau of Economic Research (NBER), Working Paper Series, No. 9110 (August); also published as Centre for Economic Policy Research, Discussion Paper, No. 3532 (September).

Blom, Andreas, Pinelopi Goldberg, Nina Pavcnik, and Norbert Schady (2003), Trade liberalization and labor market adjustment in Brazil, World Bank, Policy Research Working Paper, No. 2982 (February).

Bourguignon, Francois and Christian Morrisson (2002), Inequality among world citizens: 1820-1992, American Economic Review, Vol. 92, No. 4 (September), pp. 727-44.

Bourguignon, François et al. (2002), Making sense of globalization: a guide to the economic issues, Centre for Economic Policy Research, Policy Paper, No. 8 (July).

Boyer, Robert and Daniel Drache (eds.) (1996), States against markets: the limits of globalization, New York: Routledge.

Brown, Drusilla, Alan Deardorf, and Robert Stern (2003), The effects of multinational production on wages and working conditions in developing countries, National Bureau of Economic Research (NBER), Working Paper, No. 9669 (April). 
Buira, Ariel (2002), 'Reforming the governance of the Bretton Woods institutions,' in: The OPEC Fund for International Development (OPEC Fund), Financing for Development, Pamphlet Series 33, Vienna: OPEC Fund, pp. 213-55.

Buira, Ariel (2003), 'The governance of the IMF in a global economy,' in Ariel Buira (ed.) Challenges to the World Bank and IMF: developing country perspectives, pp. 13-36.

Burtless, Gary, Is the global gap between rich and poor getting wider? mimeo, PowerPoint presentation available on the internet: www.brook.edu/gs/fesearch/projects/glig/glig_hp.htm.

Cagatay, Nilufer (2001), Trade, gender and poverty, Background paper to the UNDP Project on Trade and Sustainable Development, (October). Available on the internet:

http://www.undp.org/mainundp/propoor/docs/pov tradegenderpoverty doc.pdf.

Chambers, Julia (2000), Gender and globalisation: trade liberalisation and gender equality, Background paper for the DFID white paper on "Eliminating World Poverty: Making Globalisation Work for the Poor." Available on the internet:

http://www.globalisation.gov.uk/BackgroundWord/GenderAndGlobalisationJuliaChamber s.DOC.

Chang, Ha-Joon (2003), Globalisation, economic development and the role of the state, Penang: Third World Network; and London: Zed Books.

Chau, Nancy H. and Ravi Kanbur (2001), The race to the bottom, from the bottom, CEPR Discussion Paper, No. 2687 (February).

Cigno, Alessandro, Furio C. Rosati and Lorenzo Guarcello (2002), Does globalization increase child labor? World Development, Vol. 30, No. 9 (September), pp. 1579-89.

Cornia, Giovanni Andrea (ed.) (2002), Harnessing globalisation for children, New York: United Nations Children's Fund (UNICEF). Available on the internet: http://www.uniceficdc.org/research/ESP/globalization/globalization index.html

Cornia, Giovanni Andrea (ed.) (2004), Inequality, growth and poverty in an era of liberalization and globalization,Oxford:Oxford University Press.

Cornia, Giovanni Andrea and Julius Court (2001), Inequality, growth and poverty in the era of liberalization and globalization (Policy-focused brief drawing on UNU/WIDER's research project Rising Income Inequality and Poverty Reduction: Are The Compatible?); Helsinki, UNU/WIDER; also available on the internet: http://www.wider.unu.edu/.

Cornia, Giovanni Andrea and Sampsa Kiiski (2001), Trends in income distribution in the post-World War II period, WIDER Discussion Paper, No. 2001/89 (September). Available on the internet: http://www.wider.unu.edu/.

Davis, Carlton G., Clive Y. Thomas and William A. Amponsah (2001), Globalization and poverty: lessons from the theory and practice of food security, American Journal of Agricultural Economics, Vol. 83, No. 3 (August), pp. 714-21.

Deacon, Bob (2000), Globalisation: a threat to equitable social provision? IDS Bulletin (University of Sussex, Institute of Development Studies), Vol. 31, No. 4(October), pp. 32-41; also published as: Globalization and social policy: the threat to equitable welfare, Geneva: UNRISD, Occasional Papers; and Social Policy Review, Vol. 12 (Social Policy Association, UK).

Deacon, Bob (2001), 'International organisations, the European Union and global social policy,' in: Robert Sykes, Bruno Palier, and Pauline M. Prior (eds.) Globalization and the European Welfare States: Challenges and Change, Houndmills, Basingstoke, Hampshire and New York: Palgrave Macmillan.

Deacon, Bob (2002), Globalization and the challenge for social security, in: Ronald Sigg and Christina Behrendt (eds.), Social Security in the Global Village, New Brunswick: Transaction Publishers. 
Deacon, Bob (2003), Global social governance reform, GASPP Policy Brief, No. 1 (January). Available at: http://www.gaspp.org/publications/brief1_summary.htm.

Deacon, Bob (with Michelle Hulse and Paul Stubbs) (1997), Global Social Policy: International Organizations and the Future of Welfare, London: Sage Publications Ltd.

Debrah, Yaw A. and Ian G. Smith (eds.) (2002), Globalization, employment and the workplace: diverse impacts, London; New York: Routledge.

Dolvik, Jon Erik and Liv Torres (2002), Globalisation, work, and labour standards, Norwegian Ministry of Foreign Affairs, The Globalisation Project, Report No. 9 (April). Available at: http://odin.dep.no/archive/udvedlegg/01/03/rapp9064.pdf.

Economic Commission for Latin America and the Caribbean (ECLAC) (2002), Globalization and development, Santiago, Chile: ECLAC (April).

Edmonds, Eric and Nina Pavcnik (2002), Does globalization increase child labor? Evidence from Vietnam, National Bureau of Economic Research (NBER), Working Paper Series, No. 8760 (February).

Eichengreen, Barry (2002), Capitalizing on globalization, Asian Development Review, Vol. 19, No. 1, pp. 14-66.

Emadi-Coffin, Barbara (2002), Rethinking international organization: deregulation and global governance, London: Routledge.

Freeman, Richard B. (1998), What role for labor standards in the global economy? Draft for discussion, Harvard University. Available on the internet: http://www.nber.org/ freeman/Papers\%20on\%20RBF\%20website/un-stan.pdf

Freeman, Richard, B. (2003), Trade wars: the exaggerated impact of trade in economic debate, National Bureau of Economic Research (NBER), Working Paper, No. 10000 (September).

Geider, William (1997), One world, ready or not: the manic logic of global capitalism, New York: Allen Lane.

Ghose, Ajit K. (2003), Jobs and Incomes in a Globalizing World, Geneva: International Labour Office

Gill, Stephen, (ed.) (1997), Globalization, democratization, and multilateralism, New York: St. Martin's Press.

Ginther, Donna K. and Madeline Zavodny (eds.) (2002), Technology, growth and the labor market, Dordrecht, Boston, and London: Kluwer Academic Publishers.

Gough, Ian (2001), Globalization and Regional Welfare Regimes: The East Asian Case, Global Social Policy, Vol. 1, No. 2 (August), pp. 163-89.

Greenaway, David and Douglas Nelson (2001), Globalisation and labour markets: literature review and synthesis, University of Nottingham, Leverhulme Centre for Research on Globalisation and Economic Policy, Research Paper, No. 2001/29.

Gudgeon, Peter S. (2001), Globalization and rural poverty reduction: the role of the United Nations system - contrasting styles and competing models, Paper prepared for the Expert Group Meeting on Globalization and Poverty Reduction: Can the Rural Poor Benefit from Globalization? New York: United Nations (November, 8-9, 2001); available at: http://www.un.org/esa/socdev/poverty/poverty-egm.htm.

Hagen, Katherine A. (2003), The International Labour Organization: can it deliver the social dimension of globalization? Friedrich Ebert Stiftung (Geneva Office), Dialogue on Globalization, Occasional Papers, No. 11 (October). Available at: http://fes.globalization.thinkvisually.de/pubDriver/clients/fesDog/attachments/991231_01_xxxx.pdf 
Hart, Jeffrey A. and Aseem Prakash (1997a), The decline of 'embedded liberalism' and the rearticulation of the Keynesian welfare state, New Political Economy, Vol. 2 (March), pp. $65-78$

Hart, Jeffrey A. and Aseem Prakash (1997b), Strategic trade and investment policies: implications for the study of international political economy, The World Economy, Vol. 20, No. 4 (July), pp. 457-76.

Hayter, Susan, Gerhard Reinecke and Raymond Torres (2001), South Africa (Studies on the social dimensions of globalization), Geneva: International Labour Office.

Henry, Miriam, Bob Lingard, Fazal Rizvi, and Sandra Taylor (2001), The OECD, globalisation and education policy, Oxford: Pergamon (for the IAU Press).

International Monetary Fund (IMF) (2000), World Economic Outlook May 2000: Asset Prices and the Business Cycle, Washington, DC: International Monetary Fund.

Jacobs, Didier (2002), 'Democratizing Global Economic Governance,' in: Jim Weaver, Didier Jacobs and Jamie Baker (eds.), After Neoliberalism: Economic Policies That Work for the Poor, Washington, DC: New Rules for Global International Finance, pp. 45-63.

Kaplinsky, Raphael (2001), Globalisation and economic insecurity, IDS Bulletin, University of Sussex, Institute of Development Studies, Vol. 32, No. 2 (April), pp. 13-24.

Khan, Azizur Rahman, Keith Griffin, and Carl Riskin (1999), Income distribution in urban China during the period of economic reform and globalization, American Economic Review, Vol. 89, No. 2 (May), pp. 296-300.

Khor, Martin (2001), Rethinking globalization: critical issues and policy choices, New York, NY: Zed Books Ltd.; previously published as: Khor, Martin (2000), Globalization and the South: some critical issues, United Nations Conference on Trade and Development (UNCTAD), Discussion Paper, No. 147 (April). Available on the internet: http://www.unctad.org/en/docs/dp 147.en.pdf

Kohl, Richard (ed.) (2003), Globalisation, poverty and inequality, Paris: Development Centre of the Organisation for Economic Co-operation and Development (OECD).

Köhler, Horst (2003), The challenge of globalization and the role of the IMF; Address at the Annual Meeting of the Society for Economists and Management at Humboldt university, Berlin (May 15). Available at: http://www.imf.org/external/np/speeches/2003/051503.htm.

LeeEddy (1998). The Asian Finacial Crisis, Geneva.ILO

Lee, Eddy (2000), Globalization and employment: the new policy agenda, Development, Vol. 43, No. 2 (June), pp. 18-20.

Maskus, Keith E. (1997), Should core labor standard be imposed through trade policy? World Bank, Policy Research Working Paper, No. 1817 (August).

Masson, Paul R. (2001), Globalization: facts and figures, Washington, DC: International Monetary Fund, Research Department, IMF Policy Discussion Paper; PDP/01/4 (October).

McCann, Gerard and Stephen McCloskey (eds.) (2003), From the local to the global: key issues in development studies, London and Sterling, VA: Pluto Press.

Memedovic, Olga, Arie Kyvenhoven and Willem T. M. Molle (eds.) (1998), Globalization of Labour Markets: Challenges, Adjustment and Policy Response in the EU and LDCs, Dordrecht, Boston, and London: Kluwer Academic Publishers.

Milanovic, Branko (2002), Can we discern the effect of globalization on income distribution? Evidence from household budget surveys; Washington, DC: World Bank, Policy Research Working Paper, No. 2876 (April). Available on the internet: http://econ.worldbank.org/files/17877_wp2876.pdf. 
Miller, Carol and Jessica Vivian (2002), Women's Employment in the Textile Manufacturing Sectors of Bangladesh and Morocco, Geneva: UNRISD in co-operation with the United Nations Development Programme (UNDP).

Mittelman, James H. (ed.) (1996), Globalization: Critical Reflection, Boulder, Colorado: Lynne Rienner.

Moghadam, Valentine M. (2001), Gender and globalization: female labor and women 's mobilization, Journal of World System Research (JWSR). Available on the internet: http://csf.colorado.edu/jwsr/archive/vol5/vol5 number2/v5n2 split/jwsr_v5n2 moghadam. pdf.

Murshed, S. Mansoob (2000), Globalization, marginalization and development, United Nations University (UNU)/World Institute for Development Economics Research (WIDER), Working Paper, No. 175 (February).

Murshed, S. Mansoob (ed.) (2002), Globalization, Marginalization and Development, London: Routledge.

Nayyar, Deepak (2001), 'Globalization: what does it mean for development?' in: Jomo K.S. and Shyamala Nagaraj (eds.) (2001), Globalization versus Development, Houndmills, Basingstoke, Hampshire and New York: Palgrave, pp. 1-25.

Nayyar, Deepak (ed.) (2002), Governing Globalization: Issues and Institutions, Oxford: Oxford University Press.

Norton, Andy (2000), Can there be a global standard for social policy? The 'social policy principles' as a test case, ODI Briefing Paper (May).

Norton, Andy and Sean Conlin (2000), Globalisation processes and the implications for the development of global responses in the field of social policy, Background paper for the DFID white paper on "Eliminating World Poverty: Making Globalisation Work for the Poor" (August). Available on the internet:

http://www.globalisation.gov.uk/BackgroundWord/GlobalProcessesAndyNortonScanConli $\underline{\text { n.doc }}$

Ocampo, José Antonio and Juan Martin (eds.) (2003), Globalization and development: a Latin American and Caribbean perspective, Palo Alto, Calif.: Stanford Social Sciences, Stanford University Press and Washington, DC: World Bank.

Organisation for Economic Co-operation and Development (OECD) (1995), Trade and labour standards: a review of the issues, Paris: OECD.

Organisation for Economic Co-operation and Development (OECD) (1996), Trade, employment, and labour standards: a study of core workers' rights and international trade, Paris: OECD.

Oxfam America (2002), Global Finance Hurts the Poor: Analysis of the impact of North-South private capital flows on growth, inequality and poverty, Boston: Oxfam America (May).

Oxfam International (2002), Rigged Rules and Double Standards: Trade, Globalisation, and the Fight Against Poverty, Oxford: Oxfam International.

Paratian, Rajendra and Raymond Torres (2001), Bangladesh (Studies on the social dimensions of globalization), Geneva: International Labour Office.

Perraton, Jonathan (2001), Review of: Workers without frontiers: the impact of globalization on international migration, Journal of Development Studies, Vol. 37, No. 5, pp. 165-6.

Prasad, Eswar, Kenneth Rogoff, Shang-Jin Wei and M. Ayhan Kose (2002), Effects of financial globalization on developing countries: some empirical evidence, Washington, DC: International Monetary Fund (March), available at: http://www.imf.org/external/np/res/docs/2003/031703.pdf. 
Rama, Martín (2003), Globalization and workers in developing countries, World Bank, Policy Research Working Paper, No. 2958 (January).

Reinecke, Gerhard and Raymond Torres (2001), Chile (Studies on the social dimensions of globalization), Geneva: International Labour Office.

Rodrik, Dani (1996), 'Labor standards in international trade: do they matter and what to do about them' in Robert Z. Lawrence, Dani Rodrik, and John Whalley (eds.), Emerging agendas for global trade: high stakes for developing countries, Policy Essay, No. 20, Washington: Overseas Development Council.

Rodrik, Dani (1997), Sense and nonsense in the globalization debate, Foreign Policy, No. 107 (Summer), pp. 19-37.

Rodrik, Dani (2001), 'The global governance of trade as if development really mattered', Background paper for the UNDP's Trade and Sustainable Human Development Project, New York: UNDP.

Romero, Ana Teresa and Raymond Torres (2001), Switzerland (Studies on the social dimensions of globalization), Geneva: International Labour Office.

Scheve, Kenneth F. and Matthew J. Slaughter (2002), Economic insecurity and the globalization of production, National Bureau of Economic Research (NBER), Working Paper, No. 9339.

Shorrocks, Anthony and Rolph van der Hoeven (eds.) (2004), Growth, inequality and poverty: prospects for pro-poor economic development, Oxford: Oxford University Press.

Siebert, Horst (1997), An institutional order for a globalizing world economy, Institut für Weltwirtschaft an der Universitat Kiel, Working Paper, No. 807 (April).

Siebert, Horst (ed.) (2003), Global governance: an architecture for the world economy, Berlin and New York: Springer.

Singh, Ajit and Rahul Dhumale (2000), Globalization, technology, and income inequality: a critical analysis, World Institute for Development Economics Research (UNU/WIDER), Working Paper, No. 210 (December). Available on the internet: http://www.wider.unu.edu/publications/wp210.pdf.

Solimano, Andrés (2001), International migration and the global economic order: an overview, Washington, DC: World Bank, Development Research Group, Macroeconomics and Growth, Policy Research Working Paper, No. 2720 (November).

Srinivasan, T. N. (1994), 'International labor standards once again!' in: Bureau of International Labor Affairs (ed.), International labor standards and global economic integration: proceedings of a symposium, Washington, DC: Bureau of International Labor Affairs, U.S. Department of Labor.

Stalker, Peter (2000), Workers without frontiers: the impact of globalization on international migration, Boulder, CO: Lynne Rienner Publishers; Geneva: ILO.

Stiglitz, Joseph E. (2002), Employment, social justice and social well-being, International Labour Review, Vol. 141, No. 1-2, pp. 9-29.

Stiglitz, Joseph E. (2003), The roaring nineties: a new history of the world's most prosperous decade, New York: W. W. Norton \& Company.

Storm, Servaas and C.W.M. Naastepad (eds.) (2001), Globalization and economic development: essays in honour of J. George Waardenburg, Cheltenham, UK; Northampton, MA: Edward Elgar.

Torres, Raymond (2000), Republic of Korea (Studies on the social dimensions of globalization), Geneva: International Labour Office.

Torres, Raymond (2001), Towards a socially sustainable world economy: an analysis of the social pillars of globalization, Geneva: International Labour Office. 
Torres, Raymond, Christine Enzler, Gerhard Reinecke and Ana Teresa Romero (2001), Poland (Studies on the social dimensions of globalization), Geneva: International Labour Office.

Tzannatos, Zafiris (1999), Women and labor market changes in the global economy: growth helps, inequalities hurt and public policy matters, World Development, Vol. 27, No. 3 (March), pp. 551-69.

United Nations Conference on Trade and Development (UNCTAD) (eds.) (1996), Globalization and liberalization: effects of international economic relations on poverty, New York and Geneva: UNCTAD.

Van der Hoeven, Rolph (2000), Labour markets and income inequality: what are the insights after the Washington Consensus? UNU-WIDER working paper no 209,Dec 2000,Helsinki,UNUWIDER

Van der Hoeven, Rolph and Lance Taylor (2000) Introduction: structural adjustment, labour markets and employment: some considerations for sensible people, The Journal of Development Studies, Vol. 36, No4 (April 2000), pp. 57-65.

Weisbrot, Mark and Dean Baker (2002), The relative impact of trade liberalization on developing countries, Briefing Paper, Washington, DC: Center for Economic and Policy Research (June). Available on the internet:

http://www.cepr.net/Will\%20Trade\%20Make\%20Developing\%20Countries\%20RichFINAL3.pdf.

Weisbrot, Mark, Dean Baker, Egor Kraev and Judy Chen (2001), The scorecard on globalization 19802000: twenty years of diminished progress, Center for Economic and Policy Research (CEPR), Washington. Available on the internet: http://www.cepr.net/globalization/Scorecard.pdf.

Weisbrot, Mark, Robert Naiman and Joyce Kim (2000), The emperor has no growth: declining economic growth rates in the era of globalization, Center for Economic and Policy Research (CEPR), Washington. Available on the internet: http://www.cepr.net/IMF/The Emperor_Has No Growth.pdf.

White, Ben (1996), Globalization and the child labour problem, Journal of International Development, Vol. 8 (November-December), pp. 829-39.

Wolfensohn, James D. (2001), The challenges of globalization: the role of the World Bank (Address to the Bundestag, Berlin, Germany April 2, 2001), Washington, DC: World Bank.

Wolfensohn, James D. (2003), A new global balance: the challenge of leadership (Address to the Board of Governors, Dubai, United Arab Emirates, September 23, 2003), Washington, DC: World Bank.

Woolcock, Michael (2001), Globalization, governance and civil society, Background paper to the World Bank's Globalization report. Available on the internet: http://econ.worldbank.org/prr/subpage.php?sp=2477.

World Bank (2002), Globalization, growth, and poverty: building an inclusive world economy (A World Bank Policy Research Report), New York and Washington, DC: Oxford University Press and World Bank. Available on the internet: http://econ.worldbank.org/prr/subpage.php?sp=2477.

World Bank (2003), Global development finance, 2003, Washington, DC: World Bank.

Yeates, Nicola (2001), Globalization and social policy, London: Sage Publication.

Yeates, Nicola (2002), Globalization and social policy: from global neoliberal hegemony to global political pluralism, Global Social Policy, Vol. 2, No. 1 (April), pp. 69-91. 


\section{Policy Integration Department Working Papers prepared for the World Commission on the Social Dimension of Globalization}

No. 16 International finance: Meeting the needs of people in developing countries, José Guilherme Almeida dos Reis

No. 17 The gender dimensions of the globalization of production, Stephanie Barrientos, Naila Kabeer and Naomi Hossain

No. 18 Social exclusion in the context of globalization, Jan Breman

No. 19 Gender and globalization: A macroeconomic perspective, Çağatay Nilüfer and Ertük Korkurt

No. 20 Globalization, social exclusion, and work: with special reference to informal employment and gender, Marilyn Carr and Martha Chen

No. 21 Resources for social development, Anthony Clunies Ross

No. 22 Does the new international trade regime leave room for industrialization policies in the middle-income countries?, Alisa DiCaprio and Alice Amsden

No. 23 Social dimension of globalization in Latin America: Lessons from Bolivia and Chile, Alvaro García Hurtado

No. 24 Globalization: Social impact and policy actions: A partly annotated bibliography, Bernhard Gunter and Rolph van der Hoeven

No. 25 The social dimension of global production systems, Susan Hayter

No. 26 Reforming global economic and social governance:

a critical review of recent programmatic thinking, Jeremy Heimans

No. 27 Corporate social responsibility: An issues paper, Michael Hopkins

No. 28 Upgrading in global value chains, John Humphrey

No. 29 Implications of globalization and economic restructuring for skills development in Sub-Sahara Africa, Richard K. Johanson

No. 30 The outcome and impact of the main international commissions on development issues, Frédéric Lapeyre

No. 31 Globalization and structural adjustment as a development tool, Frédéric Lapeyre

No. 32 Globalization and perceptions of social inequality, Malte Luebker

No. 33 The changing structure of trade linked to global production systems:

What are the policy implications?, William Milberg

No. 34 Corporate social responsibility: An overview of principles and practice, Jill Murray

No. 35 Inclusive development strategy in an era of globalization, Ignacy Sachs

No. 36 Social consequences of the globalization of the media and communications sector: Some strategic considerations, Seán Ó. Siochrú

No. 37 Globalization, history and international migration - A view from Latin America, Andrés Solimano

No. 38 Towards a different kind of globalization, or how the anti-globalizers view the world, Gijsbert van Liemt 